\title{
"Versos y marchas para las procesiones": música instrumental durante los desplazamientos ceremoniales en las instituciones eclesiásticas españolas entre ca. 1750 y ca. 1830
}

\author{
"Versos and Marches for Processions": Instrumental \\ Music During Ceremonial Translations at Spanish \\ Ecclesiastic Institutions between ca. 1750 and ca. 1830
}

La integración de la música para conjuntos instrumentales en el ceremonial religioso durante el tránsito del siglo XVIII al XIX es una temática que ha cobrado cierta relevancia en los últimos años en la agenda musicológica española e hispanoamericana. En el presente texto se analiza concretamente la inclusión de música instrumental durante aquellas ceremonias o actos religiosos que, como las procesiones, se caracterizaban por el desplazamiento de comitivas más o menos numerosas. El análisis de la documentación administrativa procedente de dieciséis instituciones eclesiásticas españolas evidencia, por un lado, la pervivencia de los ministriles en estas ceremonias hasta bien entrado el siglo XIX, en su función tradicional de alternar con el coro o la capilla de música, y revela, por otro, la participación de los conjuntos instrumentales modernos desde ubicaciones fijas, en sustitución del órgano o de los propios ministriles, con el objetivo de solemnizar el movimiento de las procesiones, los celebrantes y/o las autoridades religiosas. Finalmente, algunos repertorios musicales, titulados como versos o marchas, ilustran el tipo de piezas que podían escucharse durante estos eventos.

Palabras clave: instituciones eclesiásticas españolas, ceremonias religiosas, procesiones, música instrumental, ministriles, versos orquestales, marchas.

The integration of music for instrumental ensembles into religious ceremonies during the transition from the eighteenth to the nineteenth centuries is a subject that has gained importance in recent years in Spanish and Spanish-American musicology. This article analyses the inclusion of instrumental music during these ceremonies or religious acts that, like processions, were characterised by the translation of small or large entourages. The analysis of the administrative documentation from sixteen Spanish ecclesiastical institutions shows, on the one hand, the continued existence of minstrels in these ceremonies until well into the nineteenth century, in their traditional role of alternating with the choir or the music chapel. On the other, it reveals the participation of modern instrumental ensembles from fixed locations, replacing the organ or the minstrels themselves, with the objective of solemnising the movement of the processions, the celebrants and/ or the religious authorities. Finally, certain musical repertories, titled versos or marches, illustrate the type of pieces that could be heard during these events.

Keywords: Spanish ecclesiastical institutions, religious ceremonies, processions, instrumental music, minstrels, orchestral verses, marches. 


\section{Introducción}

La interpretación de música para conjuntos instrumentales en las ceremonias celebradas en diversas instituciones eclesiásticas tuvo un desarrollo notable en España durante la segunda mitad del siglo XVIII y las tres primeras décadas del XIX. La mayoría de las instituciones mencionadas en el presente estudio son catedrales - dieciséis de las 59 existentes en España durante el periodo estudiado ${ }^{1}$-, pero se emplea la etiqueta más amplia de "instituciones eclesiásticas" porque también se hace referencia a dos monasterios, dos iglesias parroquiales y dos colegiatas ${ }^{2}$. Numerosa documentación, preferentemente ceremoniales y edictos capitulares, y algunos repertorios musicales conservados indican en qué festividades y momentos de las ceremonias se incluía este tipo de música y qué funciones cumplía. Es preciso reconocer que estas fuentes ofrecen distintas perspectivas sobre el tema analizado que es conveniente tener en cuenta a la hora de manejarlas. En primer lugar, los ceremoniales son documentos de perfil conservador, cuyo principal interés radica en revelar las obligaciones que teóricamente tenían que cumplir los músicos que formaban parte de las capillas de música. En otras palabras, regulan cómo debía efectuarse la integración de la música en las ceremonias de las distintas festividades. Por su parte, las actas capitulares suelen ofrecer una instantánea más cercana de lo que podía ocurrir en realidad, ya que tienden a centrarse en aquellos aspectos que, o bien por defecto -faltas, ausencias de los músicos-, o bien por exceso -abusos incorporados sin permiso-, no se realizaban conforme a las obligaciones escritas, requiriendo, de ese modo, la deliberación y arbitrio por parte del cabildo catedralicio. Por último, las fuentes manuscritas con notación musical, en formato partichela o partitura, son de especial atractivo, puesto que, en algunos casos, los títulos de las portadas evidencian explícitamente la vinculación con determinadas ceremonias y, por tanto, la existencia de la práctica analizada.

Los trabajos que han abordado de manera específica esta temática durante el periodo estudiado se han centrado, por lo general, en las misas mayores y en determinadas horas canónicas, aunque también han analizado el

\footnotetext{
${ }^{1}$ Estas dieciséis catedrales, por orden de aparición en el estudio, son las siguientes: Sevilla, Málaga, Plasencia (provincia de Cáceres), Córdoba, Santiago de Compostela, León, Ourense, Jaén, Burgos, Barbastro (Huesca), Cádiz, Coria (Cáceres), Salamanca, Astorga (León), Santander y Oviedo. Durante el periodo estudiado, la organización territorial de las catedrales se regía mediante demarcaciones basadas en las sedes arzobispales: concretamente, existían ocho archidiócesis (Santiago de Compostela, Sevilla, Burgos, Toledo, Granada, Zaragoza, Valencia, Tarragona) y dos obispados exentos (Oviedo y León).

${ }^{2}$ Los dos monasterios mencionados en este trabajo son el de las Descalzas Reales (Madrid) y el de Montserrat (Barcelona). Las dos iglesias parroquiales son la de Santa María del Pi, ubicada en la Ciudad Condal, y la de Santa María de Vilafranca del Penedés. Por último, las instituciones con rango de colegiata son la Seu de Manresa y la de San Pedro Apóstol en Soria.
} 
fenómeno de las siestas y el uso del término concierto en los espacios religiosos ${ }^{3}$. Por su parte, la integración de la música para conjuntos de instrumentos durante las procesiones se ha estudiado preferentemente en periodos anteriores (siglos XVI y XVII), vinculándose con la práctica de los ministriles ${ }^{4}$. No obstante, se debe mencionar también que algunos trabajos han remarcado la pervivencia del término ministril, así como de los instrumentos -por lo general, chirimía y bajón-, funciones y repertorios musicales asociados a

\footnotetext{
${ }^{3}$ Véase Stephen Bonta: "The uses of the 'Sonata da Chiesa", Journal of the American Musicological Society, 22, 1, Primavera 1969, pp. 54-84; Neal Zaslaw: "Mozart, Haydn and the Sinfonía da Chiesa", The Journal of Musicology, 1, 1, enero 1982, pp. 103-106; Neal Zaslaw: Mozart's Symphonies: Context, Performance Practice, Reception, Oxford, Clarendon Press, 1989, pp. 77-80; Francisco Javier Garbayo: La viola y su música en la Catedral de Santiago entre el barroco y el clasicismo, tesis doctoral, Universidade de Santiago de Compostela, 1995, vol. 1, pp. 26-52; Francisco Javier Garbayo: "Música instrumental y liturgia en las catedrales españolas en tiempos de barroco", Quintana, 1, 2002, pp. 211-224 (https://minerva.usc.es/xmlui/bitstream/handle/10347/6296/pg_213-226_quintanal. pdf? sequence=1\&isAllowed=y, última consulta 19-06-2020); Dámaso García Fraile: "Las 'siestas' como actividad musical en las iglesias hispanas durante el Antiguo Régimen", Nassarre, 18, 1-2, 2002, pp. 375-436; Francisco Javier Garbayo: "Documentación sobre capillas de ministriles y orquestas catedralicias: hacia una música 'quasi profana' en la liturgia de las catedrales", Memoria ecclesiae, 31, 2008, pp. 355-368, especialmente, pp. 355-368; Jazmín Rincón: "Los versos instrumentales de Ignacio Jerusalem y Stella: vestigios de un discurso sonoro en la Catedral de México", Anales del Instituto de Investigaciones Estéticas, XXXVI, 105, 2014, pp. 95-126 (http://dx.doi. org/10.22201/iie.18703062e.2014.105.2529, consulta 19-06-2020); Jazmín Rincón: "El verso instrumental: historia y función de un género musical en la Catedral de México", tesis doctoral, Universidad Nacional Autónoma de México, 2016 (https://repositorio.unam.mx/contenidos/el-versoinstrumental-historia-y-funcion-de-un-genero-musical-en-la-catedral-de-mexico-102086?c=r5jGW $\mathrm{Y} \& \mathrm{~d}=$ false $\& \mathrm{q}=* * * \& \mathrm{i}=1 \& \mathrm{v}=1 \& \mathrm{t}=$ search_0\&as=0, consulta 19-06-2020); Jazmín Rincón: "El verso instrumental entre la Nueva España y el México Independiente", Anuario Musical, 73, 2018, pp. 201214 (http://anuariomusical.revistas.csic.es/index.php/anuariomusical/article/view/250/250, consulta 19-06-2020); Héctor Santos: "Definiciones y usos del término 'concierto' en la documentación catedralicia española entre ca. 1750 y ca. 1830", Resonancias, 23, 44, enero-junio 2019, pp. 13-35 (https://doi.org/10.7764/res.2019.44.2, consulta 19-06-2020); Héctor Santos: Música orquestal en las catedrales españolas entre ca. 1770 y ca. 1840: funciones, géneros y recepción, tesis doctoral, Universidad de La Rioja, 2019, pp. 129-167 (https://dialnet.unirioja.es/servlet/tesis?codigo=232088, consulta 19-06-2020).

${ }^{4}$ Kenneth Kreitner: "The Cathedral Band of León in 1548, and When It Played", Early Music, 31, 1, febrero 2003, pp. 41-62; Juan Ruiz Jiménez: "Ministriles y extravagantes en la celebración religiosa", Políticas y prácticas musicales en el mundo de Felipe II, John Griffiths, Javier Suárez-Pajares (eds.), Madrid, ICCMU, 2004, pp. 199-239, especialmente, pp. 210-221 (https://www.academia. edu/2767690/Ministriles_y_extravagantes_en_la_celebraci\%C3\%B3n_religiosa, consulta 19-062020); F. J. Garbayo: "Documentación sobre capillas de ministriles y orquestas catedralicias", pp. 343-355; José López-Calo: La música en las catedrales españolas, Madrid, ICCMU, 2012, pp. 289310, 411-433. Un estudio de referencia que analiza la presencia de la música en las procesiones religiosas y civiles del periodo barroco (ss. XVII y primera mitad del XVIII) a través de la iconografía es Rosario Álvarez: "La música en las imágenes procesionales del arte barroco hispano", Anuario Musical, 50, 1995, pp. 87-148.
} 
ellos, durante todo el siglo XVIII y las primeras décadas del XIX en algunos contextos religiosos españoles ${ }^{5}$.

En este artículo pretendo ofrecer una panorámica sobre la integración de la música para conjuntos instrumentales durante los desplazamientos ceremoniales, entre ellos las procesiones, que tuvieron lugar en diversas instituciones eclesiásticas españolas a lo largo de la segunda mitad del siglo XVIII y las tres primeras décadas del XIX. De manera más específica, busco determinar i) en qué festividades del año litúrgico se solemnizaban estas ceremonias con música de instrumentos, ii) en qué momentos concretos participaban los conjuntos instrumentales y iii) cuál era la función que cumplía la música instrumental en el desarrollo de estas ceremonias. Para alcanzar estos objetivos, en primer lugar, incluyo una serie de ejemplos que atestiguan la pervivencia de la práctica tradicional asociada con los ministriles en ocho catedrales españolas hasta comienzos del siglo XIX. En segundo lugar, presento la documentación procedente de diez catedrales y un monasterio con la intención de corroborar que los conjuntos instrumentales también solemnizaban los desplazamientos de las procesiones, de las autoridades religiosas y de los celebrantes desde una ubicación fija. Para finalizar, analizo algunos repertorios musicales para grupos de viento o viento y cuerda vinculados explícitamente con las procesiones, los cuales se encuentran conservados en ocho instituciones religiosas: un monasterio, dos iglesias parroquiales, dos colegiatas y tres catedrales.

\footnotetext{
${ }^{5}$ Leocadio Hernández Ascunce: "Toques y pasaclaustros de la Catedral", Príncipe de Viana, 35-36, 1949, pp. 316-326 (https://dialnet.unirioja.es/servlet/articulo?codigo=2252098, consulta 19-06-2020); Ángel Mingote: Cancionero Musical de la Provincia de Zaragoza, Zaragoza, Institución "Fernando el Católico", 1950 (reed. 1981), pp. 348-354; Josep Borras, Antonio Ezquerro: "Chirimías en Calatayud. Principio y final de un proceso constructivo", Revista de Musicología, XXII, 2, 1999, pp. 62-63: "El último tercio del siglo XIX parece suponer el final del uso de chirimías y bajones en el ámbito eclesiástico hispánico, en consonancia con el ascenso de otras tendencias musicales nuevas, de suerte que estos instrumentos, más que propiamente desaparecer, se diversificaron hacia otros usos y formaciones. [...] Los numerosos testimonios de música -especialmente religiosa- escrita para conjuntos de chirimías y bajones hasta la frontera del siglo XX nos reafirman la permanencia cercana en el tiempo de esta práctica musical con instrumentos de viento "en familia", la cual nos resulta en estos momentos un poco alejada de nuestro repertorio estándar" (http://digital.csic.es/bitstream/10261/37800/1/Ezquerro-1999-Chirimias\%20en\%20 Calatayud.\%20Principio\%20y\%20final\%20de\%20un\%20proceso\%20constructivo....pdf, consulta 1906-2020); Cristina Bordas: "Tradición e innovación en los instrumentos musicales", La música en España en el siglo XVIII, Malcolm Boyd, Juan José Carreras (eds.), Madrid, Cambridge University Press, 2000, p. 207: "A su lado [refiriéndose a los instrumentos de la orquesta moderna] perviven, por supuesto, el órgano, y los tradicionales bajones y chirimías en actividades litúrgicas y paralitúrgicas que perviven en la tradición eclesiástica"; Antonio Ezquerro: Música instrumental en las catedrales españolas en la época ilustrada. (Conciertos, versos y sonatas, para chirimía, oboe, flauta y bajón -con violines y/u órgano-, de La Seo y El Pilar de Zaragoza), Barcelona, Institución "Mila i Fontanals", Departamento de Musicología, 2004; Albert Recasens (ed.): Escala diatónico-cromático-enarmónica. Canciones instrumentales a 3, a 4, a 5 y a solo (1751). Antonio Rodríguez de Hita (1722-1787), Madrid, Fundación Caja Madrid, 2009; Joseba Berrocal: La Recepción del Oboe en España en el Siglo XVIII, tesis doctoral, Universidad de Zaragoza, 2015, vol. 1, pp. 71 73, 77-80, 211-215; H. Santos: Música orquestal en las catedrales españolas..., pp. 96-99.
} 


\section{Pervivencia de los conjuntos de ministriles en las procesiones hasta ca. 1830}

La documentación catedralicia mencionada en este epígrafe revela la presencia de las chirimías - sustituidas hacia el final del periodo estudiado por oboes o clarinetes-, junto con los omnipresentes bajones, durante las procesiones. Como atestiguan los siguientes ejemplos, la función principal que se adjudicaba a estos conjuntos instrumentales era la de alternar con el coro o la capilla de música durante el transcurso de la comitiva.

Para comenzar, presento una lámina que formaba parte de una serie de ilustraciones que muestran la disposición jerárquica que debía seguirse en la procesión del día del Corpus Christi, tal y como se celebraba en Sevilla en 1747. Esta imagen refleja la participación exclusiva de los instrumentistas de viento (denominados ministriles) de la capilla de música de la catedral hispalense ${ }^{6}$. Junto con el maestro de capilla, siete cantores y seis niños de coro (seises), se pueden distinguir tres bajonistas y dos músicos con chirimías u oboes:

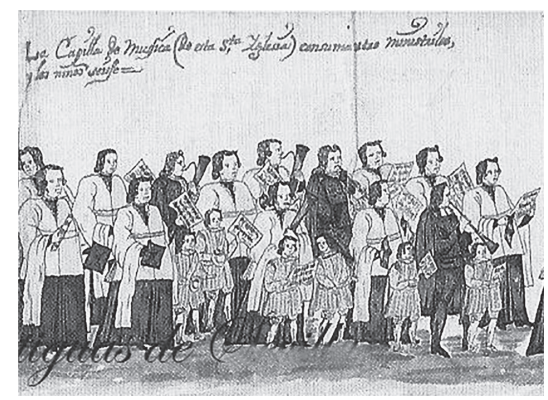

Ilustración 1. "Mapa del orden con el que se hace la Solemne Procesión del Corpus Cristi en la Sta Metropolitana, y Patriarchal Yglesia de Sevilla. Nicols de Leon Gord. ' hizo este mapa año de 1747”

\footnotetext{
${ }^{6}$ Una descripción de la evolución que sufrió la procesión del Corpus Christi en Sevilla, desde las primeras referencias del siglo XIV hasta mediados del siglo XX, se realiza en María Jesús Sanz: "La procesión del Corpus en Sevilla. Influencias sociales y políticas en la evolución del cortejo", Ars Longa, 16, 2007, pp. 55-72. Esta imagen forma parte de una colección de ocho tiras que reflejan la disposición de la procesión del Corpus en Sevilla en el año 1747, editada en facsímil en 8 tiras dibujadas de la Procesión del Corpus de Sevilla, 1747; con una carta de 1822 de José Blanco White y un artículo de Vicente Lleó Cañal, Sevilla, Comisaría de la Ciudad de Sevilla para 1992, 1991. Una descripción de las imágenes de la procesión del año 1747 se puede consultar en Ibid., pp. $62-68$ (https://www.uv. es/dep230/revista/PDF87.pdf, consulta 19-06-2020). Esta imagen también aparece analizada en estudios musicológicos que analizan tanto la presencia de la música en las procesiones de la Edad Moderna a través de la iconografía, como la capilla de música de la Catedral de Sevilla y su proyección en la ciudad a lo largo del s. XVIII. R. Álvarez: "La música en las imágenes procesionales...", pp. 106-107, lámina 21. Un análisis de la presencia y simbología de la música en la procesión del día del Corpus Christi, entendida esta como fiesta de carácter eminentemente urbano, se encuentra en Pilar Ramos: "Música y autorrepresentación en las procesiones del Corpus de la España moderna", Música y cultura urbana en la edad moderna, Andrea Bombi, Juan José Carreras, Miguel Ángel Marín (eds.), Universitat de València, 2005, pp. 243-254.
} 
Esta práctica de alternancia entre voces e instrumentos de viento durante las procesiones también se documenta en las catedrales de Málaga, Plasencia (Cáceres), Córdoba y León. En la primera, unos estatutos de 1770 indican que en las procesiones de reliquias (Processio Reliquiae) y de la Santa Cruz (Processio S. Crucis) "deben asistir los ministriles a la Procesión, alternando con los sochantres [= canto llano]"7. Este mismo documento menciona que, en las procesiones que tenían lugar después de la Nona durante las festividades de los Santos Mártires San Ciriaco y Santa Paula, patronos de la catedral (18 de junio), y de San Luis Obispo (19 de agosto), los ministriles tenían obligación de alternar con los sochantres durante toda la procesión ${ }^{8}$. Asimismo, en la procesión del Corpus y de su octava, el himno Pange Lingua se debía interpretar siguiendo la práctica de alternatim: concretamente, un versículo interpretado por los sochantres (canto llano), otro por los músicos de voz (polifonía) y, finalmente, los ministriles sustituían otro verso con el sonido de sus instrumentos (chirimías).

Un edicto capitular de la Catedral de Plasencia, fechado el 7 de junio de 1773, revela en qué posición se situaban tradicionalmente los músicos de instrumento -no se especifica cuáles, aunque lo más probable es que se refiera a los ministriles- durante la procesión del Corpus y qué función cumplían: alternar los versículos con los sochantres, es decir, con el canto llano.

Leyose Memorial de los Musicos Instrumenttistas de la Capilla de estta Santta Yglesia haciendo presentte que haviendo sido consttumbre ir en las Procesiones del Corpus immediattos a los Sochantres para la altternattiba de los Versos y haverseles seguido algunas desazones, para precaberlas suplican les señale el Cavildo lugar fijo como es el que de muchos años à estta partte han llebado para esttar mas prompottos al cumplimiento de su obligación $[\ldots]^{10}$.

Esta acta, junto con otra datada dos días más tarde -el 9 de junio-, revelan tanto las desavenencias entre los instrumentistas y el fiscal eclesiástico por la posición que debían ocupar durante la procesión del día del Corpus -que se

\footnotetext{
${ }^{7}$ Quaderno / de las obligaciones que deben / cumplir los Músicos de voz, Ministriles, / y demás Instrumentistas de la Capilla de Música de esta / SANTA IGLESIA / Catedral de Málaga, / según lo que consta de las / Tablas de su Sacristía, como lo añadido, / ó alterado, según la variedad de / los tiempos, hasta este año / de 1770. / EN MÁLAGA: / Con licencia del Excmo. Señor Gobernador Juez / de Imprentas, en la del Impresor de la Digni- / dad Episcopal, y de la Santa Iglesia / Catedral, en la Plaza, [Madrid], Ministerio de Cultura, 1985, pp. 4-5.

8 Ibid., pp. 22-23: "18 [de Junio]. Los Ss. Martyres San Cyriaco, y Santa Paula [] En la Procesión después de Nona tocan las chirimías, alternando con los Sochantres ida, y vuelta [ ] 19 [de Agosto]. San Luis Obispo. [ ] En la Procesión después de Nona tocan los Ministriles á ida, y vuelta, alternando con los Sochantres".

${ }^{9}$ Ibid., pp. 19-20: "[ ] En la Procesión cantan los Sochantres un verso de Pange lingua, los Músicos otro, y los Ministriles un toque de chirimías".

${ }^{10}$ Citado en Alicia Martín: Esplendor y ocaso en las instituciones eclesiásticas del norte de Extremadura: las prácticas musicales en las catedrales de Plasencia y Coria entre 1750 y 1839, tesis doctoral, Universidad de Extremadura, 2015, vol. 2, p. 42 . Libro 67 (1772-1773), Cabildo ordinario, lunes 7 de junio 1773, f. 433v (http://dehesa.unex.es/xmlui/handle/10662/3905, consulta 19-06-2020).
} 
celebraría al día siguiente, 10 de junio- como la solución temporal que el cabildo adoptó en esta ocasión concreta ${ }^{11}$. Los conflictos derivados por la disposición de los distintos grupos participantes en la procesión del Corpus fueron constantes, puesto que, como explica Manuel Hernández González en su libro sobre la celebración de esta fiesta en Canarias,

En una sociedad jerarquizada los elementos simbólicos juegan un papel decisivo para codificar el papel que sus individuos traslucen y desempeñan en ella. Nada como la procesión [del Corpus] ejemplificó la representación de la Iglesia de Cristo. En plena batalla contra la herejía protestante esa simbiosis de Cuerpo de Cristo y de Cuerpo Social la privilegió como escenificación de la exaltación del Dogma y de la estricta división en clases y grupos de la sociedad ${ }^{12}$.

Un informe capitular del año 1810, procedente de la Catedral de Córdoba, denuncia que el canto del Te Deum no se realizaba conforme a las rúbricas tradicionales durante las procesiones que tenían lugar fuera del recinto de la catedral ${ }^{13}$. Los músicos de voz de la capilla no cantaban los versos que les correspondían, siendo sustituidos por los instrumentistas ${ }^{14}$. Cuando este himno se cantaba dentro de la iglesia, el órgano reemplazaba a los cantores durante el segundo versículo -seguramente también en el resto de los versículos pares-, pero una voz lo decía en alto para que dicho cántico no quedara

${ }^{11}$ Ibid., p. 42. Libro 67 (1772-1773), Cabildo ordinario miércoles 9 de junio 1773, f. 435v: "[ ] en cuia inteligencia Acordo el Cavildo, que mediante à ser Vispera de Corpus, y no haver por lo que instta el tiempo lugar para ottra maior inspección y sin que estte hecho cause exemplar comdesciende por estte año sin perjuicio del dicho que en estta partte le asistte bayan en dichas Procesiones los Musicos Ynsttrumenttisttas separados algun tantto de los Sochantres, y asi se les manifiestte por el Señor Dean ó Presidentte para su inteligencia" (las cursivas son del autor).

12 Manuel Hernández: El Corpus Christi en Canarias. BienMeSabe.org, 2013, p. 23 (https://www. researchgate.net/publication/268509665_El_Corpus_Christi_en_Canarias, consulta 19-06-2020). Este mismo tipo de conflictos también los menciona Pedro Calahorra en su descripción de esta procesión en Zaragoza durante el año 1557: "No muchos años más tarde, en 1557, las mismas triviales cuestiones sobre puestos de honor y precedencias [entre los cabildos de la Seo y del Pilar] habían impedido una vez más la celebración de esta procesión". Pedro Calahorra: La música en Zaragoza en los siglos XVI y XVII. II. Polifonistas y Ministriles, Zaragoza, Institución "Fernando el Católico", 1977, p. 229.

${ }^{13}$ Córdoba, Archivo de Música de la Catedral (en adelante, E-C), Actas Capitulares, volumen 100, sábado 1 de diciembre de 1810, Sobre los abusos que se producen en el canto durante las procesiones. Citado en Luis Pedro Bedmar: La Música en la Catedral de Córdoba, a través del Magisterio de Jaime Balius y Vila (17851822), [Sevilla], Junta de Andalucía, Consejería de Cultura, 2009, pp. 595-597 (http://www. bibliotecavirtualdeandalucia.es/catalogo/es/catalogo_imagenes/grupo.cmd?path=1008912, consulta 1906-2020).

${ }^{14}$ Ibid., p. 596: "[...] Otro abuso se ha introducido en el canto del Te Deum, que se dice en las mismas procesiones y es no cantarse nada por la Capilla ni por nadie, quando toca el verso de la música [polifonía]: los instrumentos solos son los que suplen, y el citado himno por consiguiente se dice ó canta a medias" (las cursivas son del autor). 
incompleto ${ }^{15}$. Sin embargo, esto último no ocurría en las procesiones externas. Los maestros de ceremonias encargados de redactar este informe aconsejaron al cabildo que ordenara al maestro de capilla la composición de "una música sencilla para los versos del Te Deum que corresponden a la Capilla [polifonía] en su alternación con la veintena [canto llano], y que esta música sea proporcionada y respectiva al Canto Llano [del himno]"16. En sintonía con esta propuesta, el cabildo decidió suprimir finalmente la participación de los instrumentistas en lugar de los cantores, puesto que la consideraba un abuso, y estableció que el maestro compusiera "una música sencilla para los versos del Te Deum, que ahora solamente tocan los instrumentos, en la forma y modo, que se explica en dicho informe" ${ }^{17}$. Esta misma reacción por parte del cabildo se documenta también en la Catedral de Palencia en 1799, aunque en este caso con relación a los salmos que se cantaban durante las vísperas de primera clase ${ }^{18}$.

En la Catedral de León, unos estatutos del año 1664, aunque renovados por el cabildo en el año 1830, afirman que, durante el canto de las letanías -que tenían lugar en las procesiones que salían a diversas iglesias de la ciudad-, se tenía que alternar la sonoridad de los cantores ("a fabordón") y de los ministriles (se mencionan los bajones y chirimías o solo estas últimas) cuando la procesión regresaba a la catedral ${ }^{19}$. Asimismo, tanto este documento como el original de 1664 especifican la interpretación en alternancia ("a versos”) del

${ }^{15}$ Ibid., pp. 596-597: "[ ] Es verdad, que quando se canta el Te Deum en el coro [¿ubicados?] en el órgano, no se canta el $2^{\circ}$ [¿versículo?], que tocar [sic: toca] éste [refiriéndose al órgano]; pero hay una voz, que lo dice en alto [el versículo], y suple por el coro".

${ }^{16}$ Ibid., p. 597.

${ }^{17}$ Ibid.

${ }^{18}$ José López-Calo: La música en la catedral de Palencia. Vol. II. Actas Capitulares (1685-1931). Apéndices Documentales, Palencia, Diputación Provincial, 1980, p. 280. Volumen de 1799 a 1801, f. 4v, 7-1-1799: "es abuso el que los instrumentos toquen solos supliendo algunos versículos en las vísperas de $1 .{ }^{a}$ clase; así lo estimó el Cabildo, y en su consecuencia acordó que en lo sucesivo no toquen solos los instrumentos, sino que los músicos de voz canten todo el salmo alternando respectivamente a disposición del maestro de capilla".

${ }^{19}$ Estas procesiones se celebraban el día de San Marcos (25 de abril, Letanías Mayores) y el día de San Marcelo (30 de octubre). León, Archivo Capitular (en adelante, E-L), Fondo General, Tabla de las oblgs qe tienen los Musicos de esta Sta Ygla $p^{r}$ acuerdo del Cab do el año del Sor de 1664, y renobada $p^{r}$ mandato del mismo en este de 1830, sig. 3727/3, ff. 1v, 2v: "25 [Abril]. Sn Marcos [ ] Adonde fuere la Letanía hay Missa solemne a papeles y con organista. A la buelta se repite la Letanía cantando un verso a favordon y otro los Bajs o chirimías [...] $S^{n}$ Marcelo [...] Desps de oras se ba a $S^{n}$ Marcelo donde se canta missa solemne a papeles. A la buelta Letanía con cantores y chirimía alternando" (las cursivas son del autor). Juan Ruiz Jiménez, en su artículo sobre ministriles y extravagantes en la celebración religiosa durante la segunda mitad del siglo XVI, menciona tres ejemplos acerca de la participación de los ministriles en las letanías, procedentes de las catedrales de Sigüenza (Guadalajara), Pamplona y León. J. Ruiz Jiménez: "Ministriles y extravagantes...", p. 220 (nota n. $\left.{ }^{\circ} 65\right)$. 
himno Ave maris stella entre los cantores de la capilla de música y las chirimías durante la procesión del día de la patrona de la catedral (el 15 de agosto, fiesta de la Asunción de la Virgen) ${ }^{20}$.

A continuación, se ofrece una selección de ejemplos que atestiguan el incumplimiento de esta tarea por parte de los ministriles catedralicios y algunas de las soluciones que adoptaron los cabildos para fomentar la participación de los instrumentistas. En la Catedral de Santiago de Compostela, un edicto capitular de 1787 afirma que los bajones eran los instrumentos encargados de tocar durante las procesiones ${ }^{21}$. El tono imperativo que se desprende del acta se debe seguramente a que esta obligación de los bajonistas no se cumplía conforme a los gustos del cabildo y este quería regularla por escrito para asegurarse de su correcto cumplimiento. Asimismo, unos estatutos de la Catedral de León, fechados en 1797, requieren la presencia de la chirimía y el bajón en las procesiones de las principales festividades e indican la función que cumplían estos instrumentos durante las mismas:

En las funciones solemnes y en las de Primera Clase (en que no hay responsos, ni conmemoración de los Santos Mártires) se alterna el canto con los bajones y chirimías hasta el trascoro en que se detiene el preste con todo el coro, mientras la capilla de música que se pone al lado del evangelio, canta el villancico o motete dispuesto para el día ${ }^{22}$.

Casi treinta años antes, un acta capitular de mayo de 1768 de la catedral leonesa corrobora la existencia de esta misma práctica. No obstante, un canónigo solicitó al cabildo que otros instrumentos (no se revela cuáles) pudieran participar también en la procesión del Corpus, puesto que la chirimía no

${ }^{20}$ E-L, Fondo General, Obligaciones Que tiene la Capilla y demás ministros del choro de esta Santa Ygla ${ }^{a}$, sig. 3726, f. 3v: "15 [agosto] Asumpcion de N. S"a. 1 Cls. [ ] en la Procesión se ba cantando el Ave Maristela a Versos entre Capilla y Ministriles. Salese al Patio"; E-L, Fondo General, Tabla de las oblgs qe tienen los Musicos de esta Sta Ygla , sig. 3727/3, f. 2r: "15 [agosto]. La Asunción de N. Sra. 1 Clas. [ ] y en ella [refiriéndose a la procesión] se canta el Ave Maris Stella esta procesión anda $\mathrm{p}^{\mathrm{r}} \mathrm{Ygl}{ }^{\mathrm{a}}$ Claustro, y Atrio y en ella tocan a versos [ien alternancia?] la Capilla [de música] y chirimías". Esta misma práctica también se documenta en instituciones eclesiásticas de menor rango que las catedrales. Así, por ejemplo, durante las ceremonias religiosas patrocinadas por la familia Ciuró, celebradas en la iglesia parroquial de San Fructuoso de Camelás (Rosellón) en el año 1643 para conmemorar la festividad de la Concepción de la Virgen (8 de diciembre), se indica que en la procesión "se cantó el himno Ave Maris stella a canto de órgano con respuestas de los ministriles". Ascensión Mazuela-Anguita: "Polifonía, redes musicales y ceremonias rurales en los Pirineos Orientales a través de las crónicas de Honorat Ciuró (1612-1674)", Revista de Musicología, XXXIX, 2, 2016, p. 422.

${ }^{21}$ Santiago de Compostela, Archivo y Biblioteca Capitular (en adelante, E-SC), Actas Capitulares, vol. 61, f. 51, 11-9-1787: "En este cabildo se acordó que no se admita a cantar ni a tocar en el coro ni en las procesiones, ni ninguna persona que no esté admitida con plaza en él, sin expresa licencia del Cabildo, y que los bajones toquen en las procesiones [sic todo]" (las cursivas son del autor).

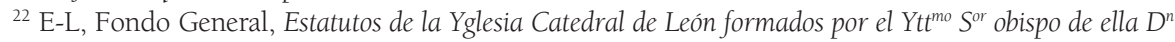

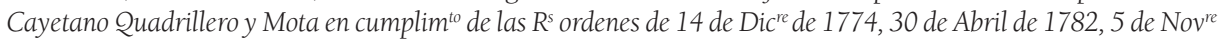
de 1785 y 26 de Octe de 1796, sig. 1827, f. 233v (las cursivas son del autor). 
acudía a esta ceremonia y los bajones no podían realizar solos esta tarea. El cabildo accedió a esta petición ${ }^{23}$. Esta última cita evidencia que la realidad no era tan fija como se deduce de la lectura de los ceremoniales. Algo similar se intuye en la Catedral de Ourense, donde la documentación catedralicia insiste en la asistencia obligada de la(s) chirimía(s) durante las procesiones hasta la tercera década del siglo XIX ${ }^{24}$, seguramente con el objetivo de fijar esta obligación por escrito para evitar o, al menos, limitar las reiteradas faltas de los músicos encargados de tocarlas ${ }^{25}$. En términos semejantes se expresaba el maestro de capilla Ramón Garay (1761-1823) en la Catedral de Jaén. En un memorial dirigido al cabildo en octubre de 1804, en el que denunciaba la decadencia por la que atravesaba la capilla de música, afirmaba que la falta de instrumentistas no solo impedía tocar una obertura o sinfonía durante el ofertorio de la misa, sino que también "se experimenta en las Tocatas o responsiones [= respuestas], qe. en las procesiones claustrales son executadas por un Bajon y obue"26.

\section{"Y tocarán los instrumentos entretanto que los Caperos llegan al Coro": música instrumental para solemnizar los desplazamientos ceremoniales}

La participación de los instrumentistas en alternancia con las voces permitía preferentemente la utilización de los instrumentos de viento, como corroboran los documentos e ilustraciones anteriores, ya que estos últimos podían tocarse fácilmente mientras se caminaba. Sin embargo, los músicos de instrumento también podían participar desde una ubicación fija, rellenando y solemnizando aquellos intervalos en los que se producían desplazamientos de la procesión o de determinados participantes (celebrantes, autoridades religiosas) por el interior

${ }^{23}$ E-L, Fondo General, Libro de actas capitulares 10043, ff. 151v-152r, 27-5-1768, Que la música e instrumentos alternen en la procesión del Corpus: "Propuso el señor Campuzano que siendo muy correspondiente al mayor culto y majestuosa ostentación que en las procesiones del Corpus alternase el coro de música e instrumentos podría servirse el cabildo si así lo consideraba mandarlo ejecutar respecto de que con la falta que hacía la chirimía no podría el bajón solo llevar este trabajo. En vista de lo cual mandó el cabildo que los señores Correctores y Maestro de Ceremonias lo dispusiesen así".

${ }^{24}$ Emilio Duro: La música en la Catedral de Ourense, [Ourense], Caixa Ourense, 1996, p. 228: "En octubre de 1814, previo examen por el maestro de capilla y el organista, fue admitido, con siete reales Dionisio Mojón, 'para tocar el violín o clarinete, según se le mande, y la chirimía en las procesiones, que debe haberla"' (las cursivas son del autor).

${ }^{25}$ Ibid., p. 219: "Fueron notables sus faltas [refiriéndose a Dionisio Mojón (1814-1826)] -comunes con [Félix] Zancada, aunque en mayor grado- en asistir con la chirimía a las "procesiones claustrales" y en las de fuera".

${ }^{26}$ Pedro Jiménez: Documentario Musical de la Catedral de Jaén II. Documentos de Secretaría, Granada, Centro de Documentación Musical de Andalucía, 1998, pp. 387-388. N. o 534. Jaén, 24-10-1804. Ramón Garay, maestro de capilla de la catedral, denuncia la decadencia de la música por falta de voces e instrumentos (http://www.bibliotecavirtualdeandalucia.es/catalogo/es/catalogo_imagenes/grupo.cmd?path=1008845, consulta 19-06-2020). 
de la iglesia o por el claustro ${ }^{27}$. Si bien es cierto que parte de la documentación consultada sigue haciendo referencia únicamente a los instrumentos de viento o al órgano, en otros casos la terminología empleada en las fuentes administrativas -instrumentistas o músicos de instrumento en lugar de ministriles- y algunos repertorios musicales conservados no solo sugieren, sino que corroboran que los conjuntos conformados por instrumentos modernos -los pertenecientes a la familia del violín, oboes y/o flautas, trompas- también podían participar en estas ocasiones ${ }^{28}$.

Tanto la salida como la entrada de las procesiones en el coro eran momentos destacados donde podía escucharse la música de los conjuntos instrumentales o del órgano, como atestiguan los siguientes ejemplos. Los estatutos de 1664, actualizados en 1830, procedentes de la Catedral de León, revelan que los músicos tenían obligación de solemnizar la salida de las procesiones, es decir, su comienzo, en determinadas festividades, tocando los bajones y chirimías - $\mathrm{O}$, en lugar de estas, los clarinetes- desde la plataforma de uno de los órganos ${ }^{29}$.

${ }^{27}$ Como evidencia Cristina Fernandes, en el entorno cortesano portugués las sinfonías cumplían esta misma función durante las ceremonias religiosas de las principales festividades: "nas grandes celebraçoes religiosas as Sinfonias assinalavam com pompa a abertura da celebraçao e o seu encerramento $e$ acompanhavam as deslocaçoes rituais do clero". Cristina Fernandes: "Sinfonias 'Al Divino': Algunas reflexoes sobre os usos da música orquestral nos espaços eclesiásticos da Monarquia", Música instrumental no periodo final do Antigo Regime: contextos, circulaçao e reportórios, Vanda de Sá, Cristina Fernandes (ed.), Lisboa, Colibri/UnIMeM-Universidade de Evora, 2014, p. 238 (las cursivas son del autor).

${ }^{28}$ En el ámbito catalán se documenta la pervivencia y simultaneidad de los conjuntos de ministriles y los conjuntos de instrumentos "modernos" hasta comienzos del siglo XIX, siendo un caso paradigmático el de la iglesia parroquial de Santa María del Mar (Barcelona), la cual, todavía en 1805, contaba con dos cuerpos diferenciados: una capilla de diecisiete músicos (maestro de capilla, organista y quince cantores e instrumentistas) y una cobla conformada por cuatro ministriles. No obstante, también se puede documentar, siguiendo el testimonio de Rafel d'Amat i Cortada, Barón de Maldà, la transformación tímbrica que experimentaron las coblas del entorno barcelonés durante la segunda mitad del siglo XVIII, pasando de los instrumentos tradicionales (gaitas, chirimías, flautas de pico, tamboriles) a los que él relaciona con el "gusto moderno" (trompas, violas, violines, violonchelos). Lluís Bertran: Musique en lieu: une topographie de l'expérience musicale à Barcelona et sur son territoire (1760-1808), tesis doctoral, Université de Poitiers, Universidad de La Rioja, 2017, pp. 90 (nota 43) y 124 (https://dialnet.unirioja.es/servlet/tesis?codigo=148224, consulta 19-06-2020).

${ }^{29}$ Las festividades del año litúrgico en las que se hace referencia a esta obligación son las siguientes: Circuncisión del Señor (1 de enero, 2. ${ }^{a}$ clase), Epifanía del Señor ( 6 de enero, $1 .^{a}$ clase), San Ildefonso (23 de enero), La Purificación de la Virgen (2 de febrero, 2. ${ }^{a}$ clase), La Anunciación de la Virgen (25 de marzo, 2. ${ }^{a}$ clase), San Isidoro (fiesta movible, 1. ${ }^{a}$ clase), segundo domingo después de Pascua (fiesta movible), La translación de San Claudio, Lupercio y Victorio (22 de abril), La Invención de la Santa Cruz (3 de mayo, 2. ${ }^{a}$ clase), San Juan Bautista (24 de junio, $1 .{ }^{a}$ clase), San Pedro y San Pablo (29 de junio, $1 .^{\text {a }}$ clase), La Visitación de la Virgen (2 de Julio, 2. ${ }^{a}$ clase), Santiago Apóstol (25 de Julio, $1 .{ }^{a}$ clase), Virgen de las Nieves (5 de Agosto), La Transfiguración del Señor (6 de Agosto), La Traslación de San Froilán (11 de Agosto), La Asunción de la Virgen (15 de Agosto, 1. ${ }^{a}$ clase), San Antolín (2 de septiembre, 2. ${ }^{a}$ clase), La Natividad de la Virgen (8 de septiembre, 2. ${ }^{a}$ clase), La Exaltación de la Santa Cruz (14 de septiembre, 2. ${ }^{a}$ clase), San Froilán ( 5 de octubre), Todos los Santos (1 de noviembre, $1 .{ }^{a}$ clase), La Dedicación de la Catedral (10 de noviembre, $1 .{ }^{a}$ clase), Presentación de la Virgen (21 de noviembre, $2 .{ }^{a}$ clase), El Patrocinio de la Virgen (fiesta movible, 2. ${ }^{a}$ clase), La Concepción de la Virgen (8 de diciembre, $1 .{ }^{a}$ clase), La Expectación de la Virgen (18 de Diciembre, 2. ${ }^{a}$ clase), Natividad del Señor ( 25 de diciembre, $1 .{ }^{a}$ clase). 
A diferencia de los estatutos originales de 1664, donde se emplea en todo momento el término ministriles ${ }^{30}$, en los de 1830 se aprecia cierta ambigüedad terminológica, ya que se emplea la palabra genérica músicos, aunque todavía haciendo referencia explícita a los instrumentos característicos de los conjuntos de ministriles ${ }^{31}$.

En la Catedral de Burgos, un edicto capitular de junio de 1837 confirma la interpretación de música instrumental, designada mediante el término sonata ${ }^{32}$, al comenzar las procesiones. Dicha acta indica que era una práctica reciente y que debía suprimirse, debido a que estas composiciones instrumentales se consideraban poco apropiadas para las ceremonias religiosas ${ }^{33}$. Este fenómeno también lo he podido documentar en la corte alemana de Thurn und Taxis en Regensburg durante el magisterio de Joseph Riepel (1709-1782), Kapellmeister entre 1749 y 1782. Según indica el New Grove, se conservan cuatro sinfonías compuestas por este maestro, las cuales estaban destinadas para interpretarse antes de las procesiones solemnes:"4 sinfonías 'pro [= delante de] Prozessione Solemni’”34.

${ }^{30}$ E-L, Fondo General, Obligaciones Que tiene la Capilla sig. 3726, f. 2r: "1 [enero]. La Circuncisión de el señor. 2 Cls. [ ] al salir la Procesión tienen los Ministriles corillo".

${ }^{31}$ E-L, Fondo General, Tabla de las oblgs $q^{e}$ tienen los Musicos de esta Sta Ygla $\ldots$, sig. 3727/3, f. 1r: "1. ${ }^{\circ}$ [enero] La Circuncisión del Sor. 2 Cls. [ ] Al salir la procesión tocan los Músicos los Bajones y chirimías, o clarinetes si los hai en el corillo".

${ }^{32}$ La séptima y octava edición del Diccionario de la Real Academia Española, fechadas respectivamente en 1832 y 1837, definen sonata del mismo modo en que ya lo hacía el Diccionario de Autoridades (tomo sexto, 1739, p. 151) casi un siglo antes: "SONATA. f. Concierto de música de variedad de instrumentos. Concentus, symphonia". DICCIONARIO / DE LA LENGUA CASTELLANA / POR / LA ACADEMIA ESPAÑOLA. / Octava edición, Madrid, Imprenta Nacional, 1837, p. 697 (http://www. cervantesvirtual.com/obra-visor/diccionario-de-la-lengua-castellana--3/html/004522aa-82b2-1ldfacc7-002185ce6064.html, consulta 19-06-2020).

${ }^{33}$ José López-Calo: La música en la Catedral de Burgos. Vol. VII. Documentario musical. Actas Capitulares (V) (1776-1839), Burgos, Caja de Ahorros del Círculo Católico, 1996, p. 387. Registro 136 (1837-1839) de actas capitulares, f. 34v, 9-6-1837, Propuesta: "El señor lectoral: que se evite una sonata introducida de poco tiempo a esta parte al partir las procesiones, como impropia de la casa del Señor".

${ }^{34}$ Leonard G. Ratner, Thomas Emmerig: "Riepel, Joseph", The New Grove Dictionary of Music and Musicians, Stanley Sadie (ed.), Londres, Macmillan Publishers Limited, 2001, vol. 21, p. 368. En la página del RISM (http://www.rism.info/home.html) he conseguido localizar dos fuentes que contienen, respectivamente, una "Sonata in F / per la processione", fechada en 1752 (RISM ID n. ${ }^{\circ} 300001095$ ), y una "Symphonia pro Processione Solemni" en Do Mayor (RISM ID n. ${ }^{\circ} 300001097$ ), las cuales se conservan en la biblioteca del Monasterio Paulino (Klasztor Ojców Paulinów), ubicado en la ciudad polaca de Częstochowa. En esta institución también se conservan sonatas orquestales destinadas específicamente para las procesiones compuestas por Marcin Józef Żebrowski, músico polaco que formó parte de la capilla de dicho monasterio entre 1748 y 1765 y, posteriormente, también en 1780. Según indica la entrada del New Grove dedicada a este músico, "There is no difference in structure between his Sonatae and Andante pro processione, which are short da capo pieces played at processions during Mass". Zygmunt M. Szweykowski: "Żebrowski, Marcin Józef", Grove Music Online (https://doi.org/10.1093/ gmo/9781561592630.article.30885, consulta 19-06-2020). Dos adagios "pro processione solemni" en Fa y Re Mayor -escritos para una plantilla de dos violines, dos oboes, dos trompas, basso y órgano- los he podido localizar en la página del RISM (RISM ID n. ${ }^{\circ} 300033507$ ). 
Por lo que respecta a la llegada de las procesiones al coro, los estatutos de la Catedral de León fechados en 1797 revelan que, en las festividades de primera clase, el órgano participaba de manera independiente al finalizar estas ceremonias: "concluida la música [refiriéndose al villancico o motete cantado por la capilla] entra la procesión en el coro, tocando el órgano, hasta que el preste y ministros llegan a su lugar" 35 . De modo similar, el ceremonial de 1830 indica que el órgano tenía obligación de acompañar la procesión que precede a la ceremonia de la Kalenda de Navidad desde su salida de la sacristía hasta su entrada en el coro, sustituyendo en este cometido a los conjuntos de ministriles ${ }^{36}$.

Algunos documentos procedentes de las catedrales de Málaga y Barbastro (Huesca) atestiguan que los conjuntos instrumentales y el órgano podían cumplir, indistintamente, las mismas funciones durante las procesiones. En el caso de Málaga, la tabla de 1770 que regula las obligaciones de los músicos indica, al igual que los ceremoniales antes mencionados de León, que el órgano rellenaba el espacio temporal durante el cual la procesión entraba en el coro ${ }^{37}$. No obstante, también era una de las tareas de los ministriles solemnizar este mismo momento durante las festividades celebradas con mayor solemnidad ${ }^{38}$. Por su parte, un edicto capitular de julio de 1798 procedente de la Catedral de Barbastro ratifica la participación independiente del órgano o de los conjuntos instrumentales durante los desplazamientos del coro por el claustro en las festividades de primera clase y en las fiestas fundadas. En estos intervalos, en los que el coro permanecía callado, el cabildo consideró adecuado que, o bien los músicos de instrumento, o bien el órgano, tocasen en dichos momentos para solemnizarlos:

Propuso el Sr. Deán que el Sr. Obispo havia hecho saber al Sr. Doctoral, que parecia desairado, que en los claustros, cantada la estrofa estubiese en el tránsito [= desplazamiento] parado el coro [ $=$ sin cantar], en cuio intermedio, como en otras Yglesias, podía sonar el órgano, o tañer los músicos, y visto que en ello no había inconveniente, se encargó al Sr. Fabriquero noticiase a los músicos que en adelante, para los claustros de los días de primera clase quo ad ritum et solemnitaten, y en las

${ }^{35}$ E-L, Fondo General, Estatutos de la Yglesia Catedral de León..., sig. 1827, f. 234r.

${ }^{36}$ E-L, Tabla de las oblg $q^{e}$ tienen los Musicos de esta Sta Ygla , sig. 3727/3, f. 3r: [24 diciembre] Vigilia de Navidad. Sale la Procesión de la Sacristía: tos músicos ban [estas palabras tachadas hacen referencia a la participación de los ministriles] delante tocando toca el órgano [esta indicación sustituye a las palabras tachadas] hasta q entren todos en el coro".

${ }^{37}$ Quaderno / de las obligaciones que deben / cumplir los Músicos de voz..., p. 5: "y al entrar la Procesión por la valla [días de procesiones de reliquias (Processio Reliquiae) y de la Santa Cruz (Processio S. Crucis)], y lo que dura la adoración, toca el órgano".

${ }^{38}$ Este documento de Málaga distingue ocho categorías para clasificar las fiestas del año litúrgico en función de la cantidad de música que se integraba en ellas. Los días englobados en la primera categoría eran los de mayor solemnidad, aspecto que, desde el punto de vista musical, se traduce en una mayor participación de los músicos catedralicios. Ibid., p. 9: "NUMERACIÓN DE LOS DIVERSOS modos de servir la Música todas las Festividades del año: y a esta se refieren los días del Kalendario, para excusar repeticiones. NUM. I. [ ] En la Procesión hay toques de chirimías, y motete en la Capilla de la Encarnación. También tocan las chirimías al entrar la Procesión en el Coro" (las cursivas son del autor). 
fiestas fundadas cantada por el coro la estrofa del Himno hasta que el coro llegase al otro ángulo de la Yglesia [en ese intervalo durante el que se produce el desplazamiento], tañesen los ynstrumentos o el órgano ${ }^{39}$.

La participación exclusiva de los conjuntos de instrumentos modernos se puede documentar mediante un ejemplo procedente de la Catedral de Sevilla. Un informe capitular de esta institución fechado en enero de 1807 , que confirma la inclusión de sonatas instrumentales en el espacio del gradual ("entre la Epístola y el Evangelio") y de la poscomunión durante las misas celebradas en las festividades de primera clase, revela también que el conjunto orquestal catedralicio debía solemnizar la entrada de las procesiones en el coro:

Habiendose juntado para evaquar la Comision que con fecha de 12 de Enero del presente se sirvio V.S. darnos sobre el arreglo de varios puntos pertenecientes a la Musica, debemos decir, que informados del Maestro de Capilla parece muy facil, y sencillo que en los dias de primera clase se toque entre la Epistola y el Evangelio alguna sonata, o Pasagito agradable, y oportuno; evitando por este medio el capricho, voluntariedad, y sin duda la disonancia con que hasta aqui se ha hecho; extendiendose esto mismo al tiempo de entrar la Procesion en el Coro, y en la Poscomunion ${ }^{40}$.

En esta misma institución, un edicto de noviembre de 1811 confirma que las festividades en las que participaba la orquesta -conformada, como indica un plan de 1806, por seis violines (cuatro de ellos con instrumentos agregados), un violonchelo, un contrabajo, dos oboes (también con instrumentos agregados), dos trompas y un bajón ${ }^{41}$ - eran únicamente aquellas que tenían

\footnotetext{
${ }^{39}$ Barbastro, Archivo de la Catedral (en adelante, E-BAR), Libro de Gestis, vol. 10, f. 520v, 3-VII-1798, Que se toque el organo o ynstrumentos, alternado con el coro en las fiestas de primera clase, quoad ritum et solemnitate, y en las fiestas fundadas en los claustros que por ellas se hacen en la Yglesia. Agradezco a Miguel Ángel Marín que me facilitara un trabajo inédito de Susana Flores sobre la capilla de música de esta catedral aragonesa.

${ }^{40}$ María Luisa Montero: La música en la Catedral de Sevilla a través de sus autos capitulares Volumen IV. 1771-1830, [Granada], Centro de Documentación Musical de Andalucía, 2016, p. 869. Libro 170, f. 7v-8, 21-1-1807 (las cursivas son del autor), (http://www.centrodedocumentacionmusicaldeandalucia.es/ estaticos/publicaciones/la-musica-en-la-catedral-de-sevilla-a-traves-de-sus-autos-capitulares-volumenIV-1771-1830.pdf, consulta 20-06-2020).

${ }^{41}$ M. L. Montero: La música en la Catedral de Sevilla..., pp. 859-860. Libro 169, f. 86v, 12-91806; María Luisa Montero: Domingo Arquimbau. Maestro de Capilla de la Santa Iglesia Catedral de Sevilla. 1790-1829. Un estudio estilístico de sus misas, tesis doctoral, Universidad de Sevilla, 2001, pp. 506-507 (https://idus.us.es/handle/11441/31533, consulta 20-06-2020). El término "agregado" hace referencia a la polivalencia de los instrumentistas catedralicios. Muchos de estos músicos tenían la obligación de tocar diversos instrumentos, aunque la plaza que ocuparan solo se vinculara a uno de ellos. Así, por ejemplo, en el plan de música sevillano de 1806, el tercer y cuarto violinistas tenían agregado de bajón, el quinto de oboe y el sexto de oboe y trompa, mientras que el primer oboe tenía que ser capaz de tocar también la flauta, el fagot y el corno inglés y, el segundo, debía saber ejecutar el fagot.
} 
categoría de primera clase propia, diferenciándolas de las fiestas con aparato de primera clase ${ }^{42}$.

Los músicos de instrumento también solemnizaban en ocasiones el desplazamiento que efectuaban las autoridades religiosas por el interior de la iglesia, sin vincularse necesariamente con las procesiones. Así lo confirma, por ejemplo, un acta capitular de 1724 procedente de la Catedral de Cádiz. Durante una misa pontifical, celebrada por la proclamación del rey Luis I (1707-1724), mientras los celebrantes y el obispo salían en procesión, se revestían con las ropas ornamentales y regresaban, se indica que debían tocar "el órgano y ministriles con diferencia de instrumentos algunas sonatas hasta que se les haga señal con la campanilla del altar mayor" ${ }^{43}$. Cincuenta años más tarde, un ceremonial de 1774 procedente del Monasterio de las Descalzas Reales (Madrid), que regulaba la participación de la capilla de música en las ceremonias de consagración de los obispos, hace referencia a que la orquesta tenía que tocar una obertura al comienzo de dicho acto, así como otra para concluirlo, cumpliendo de este modo la función de honrar la entrada y salida del obispo y su comitiva ${ }^{44}$.

${ }^{42}$ M. L. Montero: La música en la Catedral de Sevilla..., p. 966. Libro 174, f. 70, 11-11-1811: "El Señor Olmo dijo, que faltaba prueba fuese mayor solemnidad la orquesta que no el Cantollano, a lo que le contesto el Infrascripto que la Santa Iglesia de Sevilla tiene distribuidos sus Ritos en la forma siguiente; Cantollano en los semidobles; de Fabordon en los dobles, segundas clases, y aparato de primera clase; y Orquesta en las primeras clases propias, prueba de que la reputa a esta [la orquesta] por la mayor solemnidad con que puede celebrar las festividades principales". (La cursiva es del autor). En esta catedral, las festividades que presentan esta categoría son: La Epifanía del Señor (6 de enero), Dedicación de la Catedral (11 de marzo), Domingo de Pascua de Resurrección (fiesta movible), Lunes y Martes de Pascua (fiestas movibles), San Isidoro Arzobispo (4 de abril), La Ascensión del Señor, Domingo de Pentecostés, lunes y martes después de Pentecostés, Corpus Christi (estos cinco días son fiestas movibles), San Juan Bautista (24 de junio), San Pedro y San Pablo (29 de junio), Santiago Apóstol (25 de julio), La Asunción de la Virgen (15 de agosto), Todos los Santos (1 de noviembre), La Presentación de la Virgen (21 de noviembre), San Clemente (23 de noviembre, día de la conquista de la ciudad por Fernando III en 1248), Purísima Concepción de la Virgen (8 de diciembre), Natividad del Señor (25 de diciembre). Véase: M. L. Montero: Domingo Arquimbau..., pp. 166-179.

${ }^{43}$ Cádiz, Archivo Histórico de la Catedral (en adelante, E-CZ), Actas capitulares, L. 25, f. 14, 20-3-1724. Citado en Marcelino Díez: La música en Cádiz: la Catedral y su proyección urbana durante el siglo XVIII, Cádiz, Servicio de Publicaciones de la Universidad de Cádiz, Servicio de Publicaciones de la Diputación de Cádiz, 2004, p. 325.

${ }^{44}$ Regla de lo que / deve hazer y Can- / tar la Capilla en / las Consagraciones / de Sres Obispos / 1774, ff. 2r, 6v. Ejemplar manuscrito de la Biblioteca Nacional de España, sig. MSS/13874: "Luego que entra en la Yglesia [el Obispo] toca la Orquesta una Obertura hasta que hagan señal con la Campanilla, que entonces dejan de tocar [ ] y dichas por el Sr Obispo Ad multos annos tres vezes, empezará la orquesta a tocar una Obertura hasta que se bayan con que se da Fin". Agradezco a Lluís Bertran que me haya facilitado noticia sobre este documento (http://bdh-rd.bne.es/viewer.vm?id=0000238007\&page=1, consulta 20-06-2020). Esta orquesta estaba conformada por músicos contratados puntualmente para estas ocasiones, ya que la plantilla que mantenía regularmente el monasterio para interpretar polifonía estaba integrada, en 1780, por dos tiples, un contralto, un tenor, un bajo, dos bajones, un arpista, un violón y tres organistas. Así lo evidencia Paulino Capdepón, en su estudio sobre los maestros de capilla de dicha institución en la segunda mitad del siglo XVIII, cuando menciona los pagos ordinarios que se realizaban "a los instrumentistas que se contratan durante la Semana Santa, Corpus y Navidades con el fin de reforzar la capilla de música del monasterio". Paulino Capdepón: "Maestros de capilla del 
La entrada en el coro de los caperos, prebendados catedralicios cubiertos por la capa pluvial ${ }^{45}$, era otro de los momentos que se solemnizaban habitualmente con la música de los conjuntos instrumentales. Así lo corroboran evidencias documentales procedentes de las catedrales de Coria (Cáceres), Burgos, Salamanca, Astorga (León) y Santander. Un acta capitular de la catedral extremeña, fechada el 1 de junio de 1761, hace referencia a esta práctica de realzar los desplazamientos de los celebrantes con música instrumental ${ }^{46}$. Es probable que los instrumentos que tenían que cumplir esta tarea eran los propios de los ministriles, al mencionarse la chirimía al comienzo de dicho documento. Pero, debido a que se emplea posteriormente el término instrumentistas y no el tradicional de ministril, no puede concretarse con claridad qué tipo de instrumentos eran los que solemnizaban estos momentos ${ }^{47}$.

En la Catedral de Burgos, he localizado dos edictos capitulares que regulan la asistencia de los instrumentistas a las procesiones. El primero, fechado en diciembre del año 1791, afirma que "antiguamente los instrumentos iban en las procesiones de seis capas tocando a tiempos" ${ }^{48}$. Esta última expresión, "tocar a tiempos", parece hacer referencia a la práctica de alternancia con las voces, como se ha documentado en el anterior epígrafe de este texto. El cabildo ordenó finalmente que los músicos de instrumento asistieran a las procesiones solemnes siguiendo esta antigua costumbre ${ }^{49}$.

Monasterio de las Descalzas Reales de Madrid en el siglo XVIII (II)", Anales del Instituto de Estudios Madrileños, XLIX, 2009, pp. 323-325 (https://xn--institutoestudiosmadrileos-4rc.es/wp-content/ uploads/2020/07/Tomo_XLIX_2009.pdf, consulta 20-06-2020).

${ }^{45}$ El Diccionario de Autoridades define capero como "El Prebendado de la Cathedral o Colegial a quien toca ponerse la capa pluvial por dias o semanas, para asistir al Choro y Altar, conforme a las Ordenanzas y Establecimientos de la Iglesia". Diccionario / de la lengua castellana, / en que se explica / el verdadero sentido de las voces, / su naturaleza y calidad, / con las phrases o modos de hablar, / los proverbios o refranes, / y otras cosas convenientes / al uso de la lengua. / Dedicado / al Rey Nuestro Señor / Don Phelipe V. / (Que Dios Guarde) / A cuyas reales expensas se hace / esta obra. / Compuesto / por la Real Academia Española. / Tomo Segundo. I Que contiene la letra C. / Con Privilegio. Diccionario de Autoridades, Madrid, Imprenta de Francisco del Hierro, Impresor de la Real Academia Española, 1729, vol. 2, p. 142 (http://bdh-rd.bne.es/viewer. vm?id=0000053799\&page $=1$, consulta 20-06-2020).

${ }^{46} \mathrm{El}$ empleo del término celebrantes se debe a que en la entrada capa pluvial del Diccionario de Autoridades se indica que dicha prenda "la usan los Prelados, y los que hacen oficio de Prestes [sacerdote encargado de decir las misas cantadas o presidir los Oficios Divinos] en diversos días de fiesta, y también los Asistentes que los acompañan, que se llaman Caperos, lo que se observa en las Iglesias Cathedrales y Colegiales". Ibid., vol. 2, p. 135.

${ }^{47}$ A. Martín: Esplendor y ocaso..., vol. 2, p. 249. Caja 48 (1760-1763), Cabildo espiritual 1 de Junio 1761: "Acordó el Cabildo que en atención a la Chirimia que se esperaba de Madrid que los instrumentistas toquen como antes en los días que era costumbre al salir los Sres Caperos de la Sacristía para el Choro, y en las otras ocasiones que se estilaba" (las cursivas son del autor).

${ }^{48}$ J. López-Calo: La música en la Catedral de Burgos. Vol. VII..., pp. 139-140. Volumen 120 de actas capitulares, f. 278, 2-12-1791, Músico instrumentista aprenda el obue. Músicos instrumentistas asistan a las procesiones solemnes.

${ }^{49} \mathrm{Ibid}$., pp. 139-140. Volumen 120 de actas capitulares, f. 278, 2-12-1791, Músico instrumentista aprenda el obue. Músicos instrumentistas asistan a las procesiones solemnes: "[ ] que por los maestros de ceremonias se intime a los referidos músicos instrumentistas que asistan a las expresadas procesiones solemnes y toquen según se practicaba antes". 
Alrededor de un año más tarde (enero de 1793), otro edicto menciona explícitamente que los instrumentistas tocarán los instrumentos de viento ("de boca") "al tiempo que concurren los caperos al coro, como se hacía antiguamente, en las festividades de seis capas, e igualmente lo ejecuten en las procesiones de esta clase, tocando los oboes en ellas y a dicho tiempo" Es decir, los músicos de instrumento (al menos, los de viento) también tenían obligación de rellenar con su música el intervalo en el que los celebrantes se dirigían al coro, no solo en las procesiones, sino también en otras ceremonias de las festividades más señaladas. Esta vinculación entre la música instrumental destinada para realzar los desplazamientos de los caperos y otras ceremonias religiosas se observa de manera evidente en unos estatutos del año 1818, copiados literalmente de unos de 1550, procedentes de la Catedral de Salamanca ${ }^{51}$. En ellos se regula la obligación que tenían los "ministriles altos" relativa a solemnizar la llegada al coro de los celebrantes encargados de oficiar las primeras y segundas vísperas en las fiestas principales $^{52}$. De manera similar a Coria, Burgos y Salamanca, un edicto capitular de la Catedral de Astorga fechado en marzo de 1827, además de evidenciar la celebración de conciertos en los que solo participaban los instrumentistas, también reglamenta que el bajón y el clarinete tocasen en las procesiones y durante la entrada de los caperos en el coro $^{53}$.

Antes de finalizar este apartado, quiero destacar unos estatutos fechados en 1770 procedentes de la Catedral de Santander, institución erigida como tal en 1754, que prescriben que los instrumentistas debían solemnizar con su música el intervalo temporal que duraba el desplazamiento de los celebrantes hasta el coro. Este documento, aunque anterior cronológicamente a los de Burgos, Salamanca y Astorga, se incluye como cierre de esta sección, ya que, para fundamentar la

\footnotetext{
${ }^{50}$ Ibid., p. 145. Vol. 120 de actas capitulares, f. 526v, 18-1-1793, Músico instrumentista pide limosna, se le dé sin ejemplar, y prevenga como a los demás toquen las fiestas de capas [sic].

${ }^{51}$ Este documento salmantino, al igual que los estatutos de León actualizados en 1830, cuyo original data de 1664, son un claro ejemplo del conservadurismo imperante en este tipo de fuentes.

52 Archivo y Biblioteca de la Catedral de Salamanca (en adelante, E-SA), Estatutos de la santa iglesia de Salamanca y reforma hecha en el año de 37, Cajón 30, n. ${ }^{\circ}$ 97, f. 95v: "Ytem ordenamos que a las primeras y segundas vísperas de los días solemnes tañan los ministriles altos a la entrada de los caperos en el coro". Los ministriles altos eran aquellos que se encargaban de tocar los instrumentos de viento tradicionalmente asignados a ellos (chirimías, bajones, sacabuches), en contraposición a los ministriles bajos, que eran los instrumentistas de cuerda. Salva Astruells: "Los ministriles altos en la corte de los Austrias mayores", Brocar, 29, 2005, p. 28 : "Con el tiempo aparece una división de los ministriles: por un lado están los ministriles bajos, que tocan instrumentos de cuerda con un sonido más débil, y por otro están los ministriles altos, que tocan instrumentos de viento de fuerte sonoridad como la chirimía, el corneto, el sacabuche, la bombarda, y el bajón, entre otros".

${ }^{53}$ Astorga, Archivo Diocesano y Archivo Capitular (en adelante, E-AS), Actas capitulares, vol. 6, f. 282v, 24-3-1827: "[ ] Se prevenga a los instrumentistas que en las procesiones y al venir las capas al coro, toquen bajón y clarinete en lugar de chirimías, como también conciertos en los días que se ha acostumbrado". Citado en María Pilar Alén: "Las capillas musicales catedralicias desde Carlos III hasta Fernando VII", España en la música de Occidente, Madrid, Ministerio de Cultura, 1987, vol. II, p. 45.
} 
inclusión de dicha tarea y facilitar de ese modo su aceptación, indica explícitamente que era una práctica habitual en diversas iglesias, afirmación que puede validarse gracias a los cuatro ejemplos mencionados anteriormente ${ }^{54}$.

\section{Versos y marchas procesionales: un repertorio funcional para los conjuntos de instrumentos}

Junto a las evidencias documentales presentadas en los dos apartados anteriores, también se han conservado repertorios instrumentales vinculados expresamente con las procesiones. El interés de estas composiciones radica principalmente en que ofrecen un ejemplo del tipo de música que podía escucharse durante estas ceremonias. De este modo, es su aspecto funcional y no tanto su interés estilístico lo que prima en este apartado.

En primer lugar, en el Monasterio de Montserrat (Barcelona) se ha localizado un manuscrito que contiene, además de dos salmos para voces y orquesta, seis piezas instrumentales compuestas por JosepVinyals (1772-1825), monje en dicha institución desde 1791 y encargado de la educación musical de los escolanos desde ca. 1800. Estas seis composiciones, fechadas en el año 1804 y escritas para un quinteto de viento conformado por dos oboes, dos trompas y un bajón o fagot, estaban concebidas para su interpretación en las procesiones del Corpus y de la Natividad de la Virgen (8 de septiembre), como atestiguan sus títulos: Quintetos / para la Procesión / de Corpus / 1804 (tres en Re Mayor) y Quintetos / para la Procesión / de la Nativi- / dad de Ntra. / Sra. / 1804 (tres en Re menor $)^{55}$. La utilización exclusiva de instrumentos de viento y el empleo de la misma tonalidad en las tres piezas de cada uno de estos juegos posibilita que estas obras se interpretasen siguiendo la práctica alternatim mientras la procesión avanzaba. De hecho, Josep Dolcet sugiere en su introducción a este repertorio que la funcionalidad explícita de estas composiciones y su reducida extensión, entre cuarenta y sesenta compases, "las asimila a los versos o versillos que se empleaban a menudo para esas funciones" $" 56$.

Un artículo de Josep María Vilar ya planteaba esta misma idea en 1991. En dicha publicación se analizan concretamente nueve piezas escritas para conjuntos de instrumentos de viento de autoría anónima, incluidas en tres fuentes manuscritas procedentes de tres instituciones religiosas ubicadas en la actual provincia de Barcelona: la parroquia de Santa María del Pi (cuatro

\footnotetext{
${ }^{54}$ Cédula de aprobación y confirmación de los estatutos de la catedral de Santander, Madrid, 1770, capítulo XXV. Citado en Julio C. Arce Bueno: La música en Cantabria, Santander, Fundación Marcelino Botín, 1994, pp. 21-22: "[ ] y tocarán los instrumentos entretanto [en el intervalo] que los Caperos llegan al Coro, según se hace, y acostumbra hacer en las Iglesias".

${ }^{55}$ Estas seis piezas se encuentran editadas en Josep Dolcet (ed.): Josep Vinyals (1772-1825). Sis Quintets per a instruments de vent (1804), Barcelona, Tritó, 1996.

${ }^{56}$ Ibid., p. 6.
} 
versos completos y uno incompleto en octavo tono), la iglesia de Santa María deVilafranca del Penedés (dos marchas en Fa Mayor) y la Seu de Manresa (dos tocatas en Sol Mayor). Estas composiciones mantienen su función de acompañar y embellecer los desfiles procesionales - en concreto, las comitivas para administrar el viático-, a pesar de los cambios estilísticos y tímbricos que se documentan en ellas ${ }^{57}$.

En la Colegiata de San Pedro Apóstol de Soria, la actual Concatedral, se conserva un juego de tres versos destinados a las procesiones claustrales, compuestos por Miguel Antonino Osanz, maestro de capilla de dicha institución entre 1781 y $1825^{58}$. En la tabla 1 se muestra el contenido de esta fuente.

Tabla 1. Versos para procesiones compuestos por Miguel Antonino Osanz para la Colegiata de San Pedro Apóstol de Soria

\begin{tabular}{|c|c|c|}
\hline \multicolumn{3}{|c|}{ 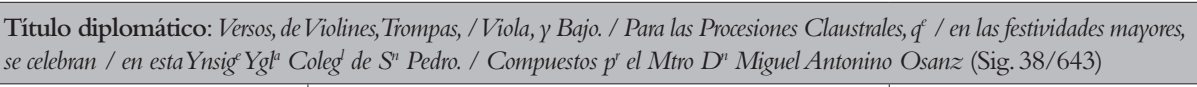 } \\
\hline Obra & Movimientos & Plantilla $^{60}$ \\
\hline Verso n. ${ }^{\circ} 1$ & Verso Primero. Mod $^{\text {to }}(12 \mathrm{cc})$. Re Mayor - C & \multirow{3}{*}{$2 \mathrm{vn} / \mathrm{va} / 2 \mathrm{hn} / \mathrm{b}$} \\
\hline Verso n. ${ }^{\circ} 2$ & Verso Segundo. Mod to $(12 \mathrm{cc})$. Si bemol Mayor - C & \\
\hline Verso n. ${ }^{\circ} 3$ & Verso Tercero. Mod $d^{\text {to }}(17 \mathrm{cc})$. Fa Mayor $-3 / 4$ & \\
\hline
\end{tabular}

${ }^{57}$ Josep María Vilar: "Sobre la música barroca per a xeremies a Catalunya i la seva evolució posterior", Eusko Ikaskuntza. Sociedad de estudios vascos. Cuadernos de sección. Música, 5, 1991, p. 121: "En part, la rao d'aquesta fossilització rau en el fet que aquests versos havien estat creats per a acompanyar una pràctica litúrgica o para-litúrgica (la de portar la comunió al malalts de la parròquia un cop a l'any [als] seus domicilis, anomenada en altres indrets, tal i com veurem més endavant, Combregar General) que es manté amb una total independència -evidentment- dels canvis en els hàbits tímbrics fins ben entrat el segle XX. És lògic, doncs, que els 'nous' instruments prenguessin el relleu als anteriors bo i mantenint la seva funció específica". Los cinco versos están escritos para un conjunto de cuatro chirimías -compuestos presumiblemente en el siglo XVII, aunque el documento en el que se integran está fechado en 1756-, las dos marchas para un ensemble conformado por dos clarinetes, dos trompas, un clarín y un fagot (ca. 1750-1760), y las dos tocatas están compuestas para dos flautas y un fagot (ca. 1820-1840).

${ }^{58}$ Montserrat Sánchez, Jesús Gonzalo (eds.): Catálogo del Archivo Musical de la Concatedral de San Pedro Apóstol de Soria, Soria, Caja Salamanca y Soria, Obra Socio-Cultural, 1992, pp. 283-284. Para conocer la biografía de este músico, véase Montserrat Sánchez, Jesús Gonzalo (eds.): Miguel Antonino Osanz (1762-1825). Concierto de flauta y orquesta, Zaragoza, Institución "Fernando el Católico", Sección de Música Antigua, 2004, pp. 3-4. Otro juego incompleto, atribuido a José María Rubio -sucesor de Osanz en el magisterio de capilla entre ca. 1826 y 1830 - y fechado en 1829 , del que solo se conserva la partichela del contrabajo y que contiene dos versos en Do menor (sig. 38/645), indica en su portada de manera explícita que eran composiciones destinadas para la procesión del Domingo de Ramos: "Versos / para la Procesión / del / Domingo de Ramos / Rubio 1829". M. Sánchez, J. Gonzalo (eds.): Catálogo del Archivo Musical de la Concatedral..., p. 314.

59 Para indicar los distintos instrumentos que conforman las plantillas, empleo el sistema de abreviaciones-General Abbreviations-propuesto por el Grove Music Online (https://www.oxfordmusiconline. com/page/General-Abbreviations, consulta 20-06-2020). 
Este repertorio puede ejemplificar el tipo de piezas que los instrumentistas tocaban para acompañar los desplazamientos de la procesión. Estos versos son de reducidas dimensiones, puesto que no superan los diecisiete compases -subdividiéndose en dos partes mediante una doble barra-,y presentan tonalidades diferentes (Re Mayor, Si bemol Mayor y Fa Mayor). A diferencia de las composiciones catalanas anteriores, esta última característica impide el uso de estas piezas sorianas en alternatim, ya que deberían tener la misma tonalidad para mantener al coro en el tono correcto. Estas composiciones requieren una plantilla de dos violines, viola, dos trompas y basso, aunque se conservan también dos partes añadidas posteriormente por otro amanuense - una para flauta, que se limita a doblar al violín primero, y otra que es un papel simplificado del segundo violín-. Estas dos partichelas copiadas a posteriori atestiguan la pervivencia y el uso de estas piezas en las ceremonias de esta institución durante el siglo XIX (véase transcripción del verso . $^{\circ} 1$ en el anexo) ${ }^{60}$.

En la Catedral de León también se conserva un manuscrito que contiene siete marchas destinadas para las procesiones, compuestas por el violinista local Juan Fernández en el año $1809^{61}$. A continuación se presenta el contenido de esta fuente.

\footnotetext{
${ }^{60}$ Un concierto para flauta del propio Osanz (sig. 37/642), escrito originalmente para flauta obligada, dos violines, dos trompas y basso, incluye otras tres partichelas, copiadas por un amanuense diferente, destinadas para una segunda flauta y dos clarinetes. Según se indica en la introducción de la edición actual de este concierto, estas últimas partichelas "son de la época de Domingo de Miguel, organista con funciones de maestro de capilla, de la concatedral de Soria hacia mitad del siglo XIX". M. Sánchez, J. Gonzalo (eds.): Miguel Antonino Osanz (1762-1825) , p. 6. La actualización de las plantillas instrumentales durante el siglo XIX es un aspecto que plantea Jazmín Rincón cuando documenta la circulación de los versos para conjuntos instrumentales entre distintas capillas eclesiásticas mexicanas: "[ ] en el acto del copiado, se solían modernizar o adaptarse [los manuscritos con versos para instrumentos] a la nomenclatura musical o instrumentación que hubiese a la mano, es decir; pasados los años y debido a su desgaste y uso meramente práctico y funcional, se les agregaron, tanto elementos de escritura posteriores, como partes de instrumentos con las que no contaba el original". J. Rincón: "El verso instrumental: historia y función ", pp. 131-132. Esta misma práctica también la menciona María José de la Torre cuando estudia la modernización del repertorio utilizado por la capilla de música de la Catedral de Málaga en las celebraciones que tenían lugar fuera de la propia catedral: "Las tareas de copia fueron comúnmente aprovechadas para introducir modificaciones en las piezas, a veces significativas (sobre todo en su texto y en su plantilla), con el fin, a menudo, de acomodarlas a nuevas necesidades o circunstancias interpretativas". María José de la Torre: "Por ser propio de los individuos de la capilla: inventarios de bienes y construcción de repertorios en la España del primer tercio del siglo XIX. El caso de la capilla de música de la Catedral de Málaga", Revista de Musicología, 39, 2, 2016, p. 476.

${ }^{61}$ Este músico aparece mencionado por primera vez como colegial que se dedica al estudio del violín en un edicto capitular de la catedral leonesa fechado en abril de 1806. E-L, Fondo General, Libro de actas capitulares 10054, f. 179v, 14-4-1806, Memorial de Juan Fernández colegial de san José para que se le permita más instrucción en el violín. En 1809, tras la muerte del primer violinista Elías Castañedo, se ofrece al cabildo para cumplir con las obligaciones inherentes al puesto de primer violín. E-L, Fondo General, Libro de actas capitulares 10055, f. 94r, 13-3-1809, Memorial del Acólito Juan Fernández ofreciéndose a desempeñar el oficio de violín 1. ${ }^{\circ}$. En junio de 1812 se marcha de León como corrobora el libro de cuentas de ese año. E-L, Fondo General, Cuaderno de cuentas de fábrica 9708, Cuentas de Fábrica dadas por el señor don Luis Díaz Otazu por Frutos de 1811 y Gastos de 1812, f. 24r. Aparece contratado como violinista en la Catedral de Tuy (Pontevedra) en abril de 1813,
} 
Tabla 2. Marchas para procesiones compuestas por Juan Fernández en 1809 para la Catedral de León

Título diplomático: Violín Primero / Marchas para Procesiones / a Dos violines trompas Flauta / y Bajo Año 1809 / en León / Por Juan Fernz (firma) (Sig. 732)

\begin{tabular}{|c|c|c|}
\hline Obra & Movimientos & Plantilla \\
\hline Marcha n. ${ }^{\circ} 1$ & Marcha 1. ${ }^{a}$ (25 cc). Re Mayor - C & \multirow{6}{*}{$2 \mathrm{vn} / \mathrm{fl} / 2 \mathrm{hn} / \mathrm{b}$} \\
\hline Marcha n. ${ }^{\circ} 2$ & 2. ${ }^{a}$ (36 cc). Mi bemol Mayor - C & \\
\hline Marcha n. ${ }^{\circ} 3$ & $\begin{array}{l}\text { 3. }{ }^{a} \text { Marcha Para La Procesión del Corpus sobre el Pange Lingua } \\
(48 \mathrm{cc}) \text {. Fa Mayor }-3 / 4\end{array}$ & \\
\hline Marcha n. ${ }^{\circ} 4$ & Marcha $4 .^{a}$ (36 cc). Re Mayor - 2/4 & \\
\hline Marcha n. ${ }^{\circ} 5$ & $A l l^{\circ} 5 \cdot^{a}$ (24 cc). Fa Mayor - C & \\
\hline Marcha n. ${ }^{\circ} 6$ & Marcha vivo $6 .^{a}(36 \mathrm{cc})$. Sol Mayor $-\mathrm{C}$ & \\
\hline Marcha $n .^{\circ} 7$ & Marcha $7 .^{a}(38 \mathrm{cc})$. Re Mayor $-2 / 4$ & $2 \mathrm{vn} / 2 \mathrm{hn} / \mathrm{b}$ \\
\hline
\end{tabular}

La plantilla que requieren estas composiciones está conformada por dos violines, una flauta -no se incluye en la última marcha-, dos trompas y acompañamiento. Como revelan los ceremoniales mencionados en el epígrafe anterior, lo más probable es que estas composiciones se escucharan durante la salida o la entrada de la comitiva en el coro, suplantando el conjunto instrumental moderno de la capilla leonesa la función adjudicada originalmente a los ministriles -bajones y chirimías/clarinetes-o al órgano.

Seis de estas siete piezas se articulan en dos partes, separadas por una doble barra de repetición: marchas n. ${ }^{\text {os }} 1$, 2, 4, 5, 6 y 7. En todos los casos, la primera parte finaliza con una semicadencia sobre el quinto grado (n. ${ }^{\text {ss }} 1,4$ y 5 ) o mediante una cadencia perfecta sobre la tonalidad de la dominante (n. ${ }^{\text {os }} 2,6$ y 7 ). En el aspecto temático, estas marchas reutilizan los materiales de la primera parte, más o menos variados, al final de la segunda, siguiendo de este modo el patrón $\mathrm{A} \| \mathrm{B}$ A'. Estas seis composiciones presentan un compás binario $(2 / 4$ o compasillo) y suelen incorporar ritmos con puntillo. Todas estas características permiten englobar estas piezas dentro del estilo de march $a^{62}$.

prolongándose su estancia en esta institución hasta principios de 1826. Joám Trillo, Carlos Villanueva: La música en la catedral de Tui, La Coruña, Diputación Provincial de La Coruña, 1987, p. 449. Volumen XXXII de actas capitulares, f. 181v, 12-4-1813; Ibid., p. 467. Volumen XXXVII de actas capitulares, f. 37, 10-3-1826. En 1818 se presentó como candidato a una plaza de violín en la Catedral de Santiago, la cual no obtuvo. Los informes de los tres examinadores nos ofrecen una descripción de su estilo interpretativo. F. J. Garbayo: La viola y su música en la Catedral de Santiago..., vol. III, pp. 188-192, docs. 92-94. Finalmente, este músico sirvió como primer violinista en la Catedral de Oviedo entre septiembre de 1826 y enero de 1856, falleciendo ocho años más tarde (1864). María Sanhuesa: "Tres inventarios musicales decimonónicos en el archivo capitular de la Catedral de Oviedo (E: OV)", Boletín del Real Instituto de Estudios Asturianos, 154, 1999, p. 11.

${ }^{62}$ Leonard G. Ratner describe de la siguiente manera el estilo de marcha: "Its natural habitats were the parade ground and battlefield, where its moderately quick duple meter, dotted rhythms, and bold manner quickened the spirit". Leonard G. Ratner: Classic Music: Expression, Form and Style, Nueva York, Schirmer, 1980, p. 16. 
Por su parte, el título específico de la tercera marcha revela la festividad y ceremonia concreta donde esta obra se interpretaba: la procesión del día del Corpus Christi. Esta composición se articula mediante el cantus firmus del himno Pange Lingua "more hispano", que se adjudica a la línea del basso. En el ejemplo musical n. 2 incluido en el anexo se puede comparar el canto llano original ${ }^{63}$ con la obra propuesta por Juan Fernández. La integración del cantus firmus en esta pieza orquestal, indicada explícitamente en la propia partichela del bajo $\left(\right.$ cantoll $\left.^{\text {no }}\right)$, es bien visible en la transcripción.

Un manuscrito anónimo en formato partitura que contiene cinco marchas, fechado en 1781 y conservado en la Catedral de Astorga (sig. 41-44), comparte características similares con esta colección de León. En la tabla siguiente se muestra el contenido de esta fuente.

Tabla 3. Colección de marchas anónimas compuestas en 1781 para la Catedral de Astorga

\begin{tabular}{|c|c|c|}
\hline \multicolumn{3}{|c|}{$\begin{array}{l}\text { Título diplomático: Marcha Nueba / Con Violines / Oboes y Tromps / Obligs / Orgo y Acopto / Año } 1781 \text { (Sig. } \\
\text { 41-44) }\end{array}$} \\
\hline Obra & Movimientos & Plantilla \\
\hline Marcha n. ${ }^{\circ} 1$ & J MJJ y A Marcha $(21 \mathrm{cc})$. Re Mayor - C & $\begin{array}{l}2 \mathrm{vn} / 2 \mathrm{ob} / 2 \mathrm{hn} \\
/ \mathrm{acc} . / \mathrm{org}\end{array}$ \\
\hline Marcha n. ${ }^{\circ} 2$ & $J M J J$ y A. sean conmigo Marcha $(20 \mathrm{cc})$. Mi bemol Mayor - C & $\begin{array}{l}2 \mathrm{vn} / 2 \mathrm{ob} / 2 \mathrm{hn} \\
/ \mathrm{acc} .\end{array}$ \\
\hline Marcha n. ${ }^{\circ} 3$ & [Sin título] $(25 \mathrm{cc})$. Re Mayor $-\not \subset$ & \multirow{3}{*}{$\begin{array}{l}2 \mathrm{vn} / 2 \mathrm{ob} / 2 \mathrm{hn} \\
/ \mathrm{acc} . / \mathrm{org}\end{array}$} \\
\hline Marcha n. ${ }^{\circ} 4$ & $\sigma^{a} J M J J y A .(14 \mathrm{cc})$. Fa Mayor - C & \\
\hline Marcha n. ${ }^{\circ} 5$ & $\begin{array}{l}\text { J MJJ Y A. Marcha prusianna de Sollaranna (28 cc). Mi bemol } \\
\text { Mayor - C }\end{array}$ & \\
\hline
\end{tabular}

El título de este manuscrito no menciona explícitamente para qué momento ceremonial estaban concebidas estas piezas. No obstante, si se tienen en consideración la información del edicto capitular de 1827 mencionado en el apartado anterior -el cual indicaba que el clarinete y el bajón tenían que solemnizar la llegada de los caperos al coro- y el sentido original que se le da al término marcha -refiriéndose no solo al desplazamiento que se efectúa de un punto a otro sino también a la música que lo acompaña ${ }^{64}$, se puede plantear

${ }^{63}$ Nancho Álvarez (ed.): Pange Lingua "more hispano" de Corporis Christi. Tomás Luis de Victoria, Ávila, Centro de Estudios Tomás Luis de Victoria, n.d. (http://www.tomasluisvictoria.es/node/1989, consulta 20-06-2020).

${ }^{64}$ Según atestigua el Diccionario de Autoridades o el de Esteban de Terreros y Pando, una de las acepciones del término marcha era la música, generalmente de tambores y clarines, que acompañaba los desfiles militares. La referencia a Prusia, estado militarista por excelencia durante el siglo XVIII, en la última marcha de esta colección astorgana corrobora esta asociación: Diccionario / de la lengua castellana..., vol. 4, p. 496: "MARCHA. Se llama en la Milicia el son que toca el tambor, o suena el clarín, con que dá à entender se pongan en marcha los soldados. Lat. Gradiens signum dare, canere"); Esteban de Terreros y 
que estas piezas se interpretaban durante este preciso momento ${ }^{65}$. No obstante, como demuestran algunas marchas orquestales conservadas en la Catedral de Málaga, este tipo de obras también podían interpretarse en diversos momentos ceremoniales, ya fuera embelleciendo el ofertorio de la misa o integrándose como interludios instrumentales en los villancicos de Kalenda de Navidad ${ }^{66}$.

Estas marchas de Astorga están escritas para una plantilla de dos violines, dos oboes, dos trompas, órgano y acompañamiento. La presencia de estos instrumentos, especialmente la del órgano, y las diferentes tonalidades de estas piezas -dos en Re Mayor, otras dos en Mi bemol Mayor y una en Fa Mayor- refuerzan la idea de que el conjunto participaba desde un lugar fijo y no en alternancia con las voces. En el ámbito estilístico, estas composiciones, que oscilan entre los quince y treinta compases, presentan características propias del estilo marcha como el ritmo binario (compasillo), las figuraciones rítmicas con puntillo y la estructura bipartita señalada por una doble barra de repetición (véase transcripción de la marcha n. ${ }^{\circ} 4$ en el anexo).

Por último, he localizado una fuente manuscrita en la Catedral de Oviedo, conformada por ocho partichelas destinadas para dos violines, dos oboes, dos trompas, órgano y violón (legajo 44-2). Dicha fuente contiene un recitativo $\left(\operatorname{Rec}^{d o}\right)$, acompañado solo por el órgano y el violón ${ }^{67}$, que precede a una marcha procesional y una pieza exclusivamente instrumental, sin los oboes, concebida para la misa (Misa). Tres evidencias corroboran que tanto el recitativo como la

Pando: Diccionario castellano con las voces de ciencias y artes y sus correspondientes en las tres lenguas francesa, latina, e italiana, Madrid, en la imprenta de la viuda de Ibarra, hijos y compañía, 1787, vol. 2, p. 527: "MARCHA, acción con que uno se aparta de algún lugar. [ ] MARCHA, vOz común en la Milicia, tomado en la misma significación [ ] MARCHA, el toque mismo de la marcha. V. Toque. Lat. Signum gradiendi. TOCAR Á MARChA, Ó LA MARChA, Ó Á MARChAR. Fr. Battre la marche, sonner. Lat. Gradiendi, eundi signum daré, canere. También una pieza de Música en que se toca alguna marcha militar. Fr. Marche" (http://bdh-rd.bne.es/ viewer.vm?id=0000022720\&page $=1$, consulta 20-06-2020).

${ }^{65}$ Las marchas orquestales compuestas por Wolfgang Amadeus Mozart, fechadas entre 1769 y 1782, también eran utilizadas como música procesional, pero en un contexto diferente, puesto que enmarcaban la interpretación de serenatas: "Mozart's orchestral marches are serenade marches -exceptions prove the rule- and were therefore used as processional music before and after, or 'framing', the Serenade itself [...] as a rule, the same processional march was played on the way to and from the serenade venue". Wolfgang Plath: Wolfgang Amadeus Mozart. Series IV. Orchestral Works. Work group 13: Dances and Marches. Section 2: Marches, Kassel; Basel, Londres, New Mozart Edition, Bärenreiter, 1978, pp. 8-9.

${ }^{66}$ Dos obras compuestas por el organista José Barrera para la Catedral de Málaga en 1784 y 1787 (Sigs. 11-9 y 11-15) se denominan marchas y estaban concebidas para su interpretación durante el ofertorio de las misas. Estas composiciones se encuentran editadas en Antonio Tomás del Pino (ed.): José Barrera (17291788). Conciertos de órgano, Fundación Gustavo Bueno, Ars Hispana, 2013, pp. 4, 6, 11-13, 77-82. Asimismo, diecinueve villancicos de Kalenda de Navidad -trece compuestos por Jaime Balius (maestro de capilla en la Catedral de Córdoba entre 1785 y 1822), cuatro por Jaime Torrens (maestro en la de Málaga entre 1770 y 1803) y dos por Juan Cuevas (maestro de nuevo en Córdoba entre 1827 y 1832)- incluyen interludios instrumentales designados como marchas. Una explicación de este tipo de composiciones orquestales se realiza en: H. Santos: Música orquestal en las catedrales españolas..., pp. 162-167, 579-583.

${ }^{67}$ La línea superior, idéntica en ambas partichelas, está escrita en clave de Do en primera, pero no incluye ninguna letra. 
marcha procesional se interpretaban, sin solución de continuidad, en un mismo momento ceremonial: i) ambas piezas aparecen tituladas como procesión, ii) comparten una misma tonalidad (Sol Mayor) y iii) entre ellas se incluye la referencia "sigue sin parar" (véase ilustración n. ${ }^{\text { }} 2$ en el anexo). A pesar de que, por el momento, no he localizado documentos administrativos de la propia catedral ovetense que revelen cómo tenían que desarrollarse las distintas ceremonias en una determinada festividad, el orden en el que aparecen las dos piezas instrumentales - primero la marcha procesional y luego la composición para la misa- coincide con la organización ceremonial que presentan los estatutos de León y Málaga (al menos en las fiestas de primera clase $)^{68}$ y con la estructura de las fiestas religiosas en el área metropolitana de Barcelona ${ }^{69}$.

La pieza orquestal destinada para la procesión se articula en dos secciones, siguiendo el planteamiento de un aria da capo (A-B-A).A diferencia de las marchas anteriores, que no superaban en general los cuarenta compases, esta obra es de mayor extensión: $42+28$ compases. La parte B presenta un contraste armónico normativo, ya que está escrita en Mi menor, relativo de la tonalidad principal (Sol Mayor $)^{70}$. En esta composición se pueden identificar las mismas características del estilo marcha que ya he comentado al analizar las composiciones de León y Astorga: compás binario (2/4), abundancia de figuraciones rítmicas con puntillo, así como la organización bipartita de la sección A.

La presencia de los instrumentos de cuerda en las procesiones viene confirmada por los repertorios musicales estudiados previamente. Pero ¿cuándo y de qué forma participaban? Como ya he sugerido en los casos de León y Astorga y como atestiguan diversas fuentes administrativas incluidas en el epígrafe anterior, lo más probable es que este tipo de conjuntos instrumentales modernos se situara en una o varias ubicaciones predeterminadas y, desde ellas, interpretara estas piezas durante los desplazamientos de la comitiva, máxime cuando

${ }^{68}$ E-L, Fondo General, Tabla de las oblg $q^{e}$ tienen los Musicos de esta Sta Ygla ..., sig. 3727/3, f. 1r: "6 [Enero] Fiesta de los Reyes. 1. a Clase. [ ] al salir la procesión tocan los Músicos en el Corillo. En la Nave mayor Villan ${ }^{c o}$. Missa solemne con vill ${ }^{c o}$. Al Ite Miss[a est] responden los del Corillo"; Quaderno / de las obligaciones que deben / cumplir los Músicos de voz, p. 9: "En la Procesión [de las festividades celebradas al número 1] hay toques de chirimías, y motete en la Capilla de la Encarnación. También tocan las chirimías al entrar la Procesión en el Coro. La Misa, con el motete, es de Papeles".

69 Según indica Lluís Bertran, "Dans tous les villages [cercanos a Barcelona] les fêtes principales présentent un déroulement presque identique, avec des événements musicaux parfaitement caractérisés [ ] (2) messe matinale avec ou sans musique le jour de la fête, parfois suivie d'une procession précédant la (3) messe solennelle en musique". L. Bertran: Musique en lieu..., p. 126.

${ }^{70}$ Uno de los conciertos para órgano de José Barrera, compuesto en 1786 y destinado para el ofertorio de la misa en la Catedral de Málaga (sig. 11-13), presenta esta misma estructura y disposición armónica: Mi bemol Mayor para la parte A y Do menor con final sobre Sol menor para la sección B. Para ver las implicaciones ceremoniales de este esquema formal en relación con esta pieza específica, véase H. Santos: Música orquestal en las catedrales españolas..., pp. 158-159. Asimismo, como ya comenté previamente, las sonatas destinadas para las procesiones del músico polaco Marcin Józef Żebrowski se articulan como piezas da capo. 
participase también el órgano. No obstante, en el ámbito barcelonés, dos representaciones iconográficas de la procesión celebrada por la beatificación de Sant Josep Oriol y el traslado de sus reliquias en 1807 ofrecen evidencias de que los instrumentos de cuerda más voluminosos, como violonchelos y/o contrabajos, podían ejecutarse mientras se caminaba ${ }^{71}$. En este mismo sentido se podría interpretar un edicto capitular de la Catedral de Plasencia, fechado en septiembre de 1807, en el que el cabildo dispensa al músico encargado de tocar el contrabajo (Antonio Pano) de acudir con él a las procesiones por su avanzada edad y por ser este un instrumento de dificil transporte ${ }^{72}$. Tocaran o no mientras el cortejo procesional avanzaba, lo que sí queda claro tras la consulta de estos documentos es que los músicos de cuerda acudían con sus instrumentos para formar parte de estas comitivas.

\section{Conclusiones}

Como se ha podido comprobar a lo largo de este estudio, la música proporcionada por los conjuntos instrumentales se integraba en las procesiones de las principales festividades de dos maneras diferentes. Por un lado, la documentación de ocho catedrales, en concreto las de Sevilla, Málaga, Plasencia, Córdoba, Santiago de Compostela, León, Ourense y Jaén, confirma la participación de los ministriles -bajones y chirimías / oboes / clarinetes- en alternancia con las voces hasta el primer tercio del siglo XIX.Asimismo, diversas piezas compuestas para conjuntos conformados por instrumentos de viento ejemplifican la pervivencia de este tipo de práctica hasta bien entrado el siglo XIX: las cancio-

${ }^{71}$ Ambos documentos se encuentran recogidos en Piscolabis librorum (http://ibrorum.piscolabis. cat/2009/07/la-beatificacio-de-sant-josep-oriol-i.html, consulta 20-06-2020). La procesión aparece representada en un formato denominado "Full de l'auca" (véase específicamente la imagen 85) y de forma impresa en "papers des rengles" (véase vídeo con el despliegue de este segundo documento, minuto 2'54"). Agradezco a Lluís Bertran que me llamara la atención sobre este caso concreto. De todos modos, Rosario Álvarez, al referirse a unas imágenes que reflejaban la disposición de la música en la procesión del Corpus, tal como se celebraba en Barcelona a finales del s. XVIII, plantea, en sintonía con los indicios que he mencionado previamente, que los instrumentos de cuerda (en este caso, seis violines y dos violones) participaban en las comitivas, pero "posiblemente solo intervendría en la música que se hacía en las estaciones, porque difícilmente se podría tocar un violón caminando". R. Álvarez: "La música en las imágenes procesionales...", p. 107.

${ }^{72}$ A. Martín: Esplendor y ocaso..., vol. 2, p. 127. Libro 89 (1807), Cabildo ordinario viernes 11 de septiembre 1807: "Se leyo Memorial del Musico Don Antonio Pano en que exponiendo haber serbido quarenta y seis años su plaza y tener edad de sesenta y dos suplica que el Cabildo se sirba concederle una limosna para alivio de sus atrasos causados por los malos temporales y enfermedades que ha pasado: suplica tambien se le conceda la [misma] preeminencia que a Don Josef Perez en atencion a las pocas fuerzas con que se halla para llevar en las Procesiones un instrumento tan embarazoso como el Contrabajo. Y el Cabildo habiendo conferenciado acordó dispensarle la necesidad de asistir a las Procesiones con dicho Contrabaxo y en quanto a la Jubilacion y limosna que pide, repita solicitud en principios de la próxima residencia" (las cursivas son del autor). 
nes para ministriles de Palencia, las composiciones de chirimías destinadas para los pasa-claustros en Zaragoza, los quintetos de Montserrat y los versos, marchas y tocatas procedentes de instituciones religiosas de Barcelona,Vilafranca del Penedés y Manresa. Por otro lado, los conjuntos orquestales modernos acompañaban y solemnizaban los desplazamientos de las procesiones o de determinados participantes, como las autoridades religiosas o los propios celebrantes, desde una posición fija, aunque no se puede descartar que también interpretaran música mientras caminaban. De este modo, este tipo de conjuntos suplantaban una de las funciones asignadas tradicionalmente a los ministriles o al órgano, como evidencian diversos documentos procedentes de las catedrales de León, Burgos, Málaga, Barbastro, Sevilla, Cádiz, Coria, Salamanca, Astorga, Santander y el monasterio madrileño de las Descalzas Reales. Las fuentes consultadas de siete de estas instituciones -León, Málaga, Barbastro, Coria, Salamanca,Astorga y Santander- únicamente enuncian, de manera teórica, la existencia de esta segunda obligación, mientras que en las cuatro restantes -Burgos, Sevilla, Cádiz y el monasterio de las Descalzas Reales- se emplean además etiquetas específicas para referirse a las composiciones que estos conjuntos instrumentales interpretaban, concretamente las de sonata y obertura. Por su parte, la conservación de cuatro manuscritos musicales vinculados con estas ceremonias, que contienen un total de dieciséis piezas, en cuatro instituciones diferentes -la Colegiata de Soria y las catedrales de León, Astorga y Oviedotambién permite corroborar la existencia de esta segunda práctica. En definitiva, el presente trabajo, en sintonía con algunas de las líneas temáticas de este dossier, ofrece una panorámica acerca de las obligaciones que tenían que cumplir los músicos de instrumento dentro de las ceremonias o actos religiosos que conllevaban algún tipo de desplazamiento y, a su vez, también presenta algunos repertorios instrumentales inéditos concebidos específicamente para dichos eventos. 
Anexo

\section{Ejemplos musicales}
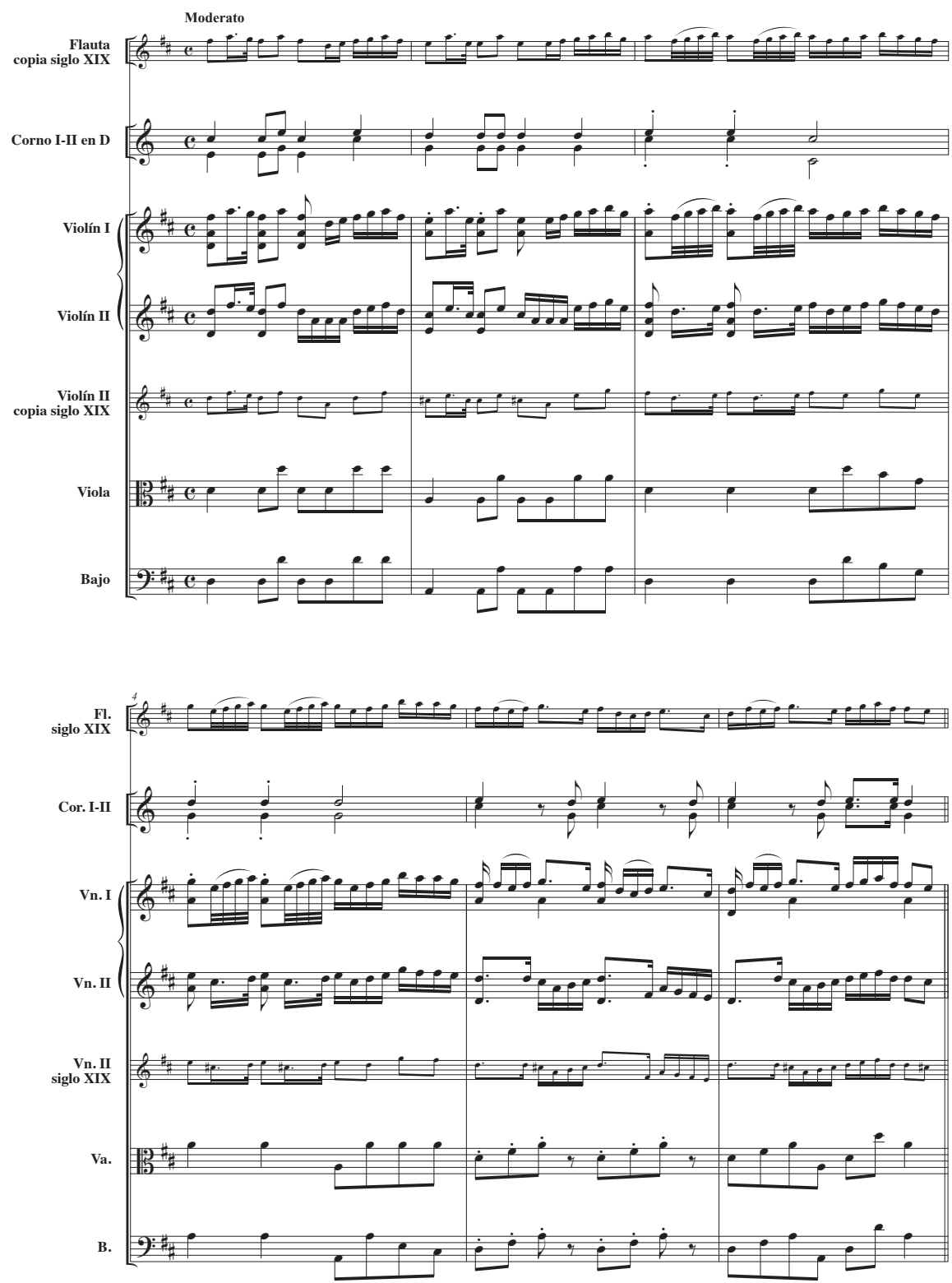

Ejemplo 1.Verso n. ${ }^{\circ} 1$ compuesto por el maestro de capilla Miguel Antonino Osanz (1762-1825) para las procesiones claustrales celebradas en la Colegiata (Concatedral) de San Pedro Apóstol de Soria 

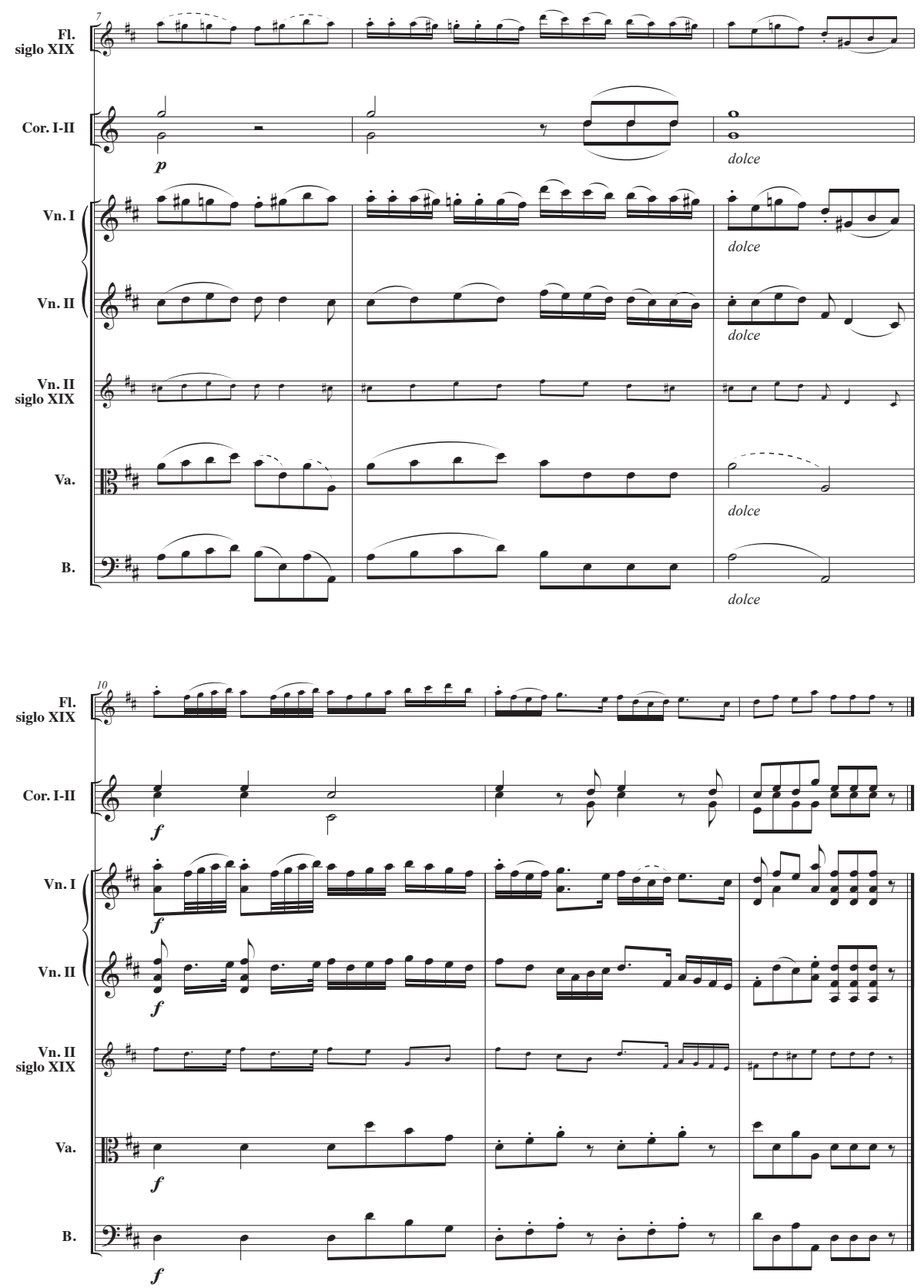

Ejemplo 1. Continuación 
"Versos y marchas para las procesiones": música instrumental durante los desplazamientos... 8I
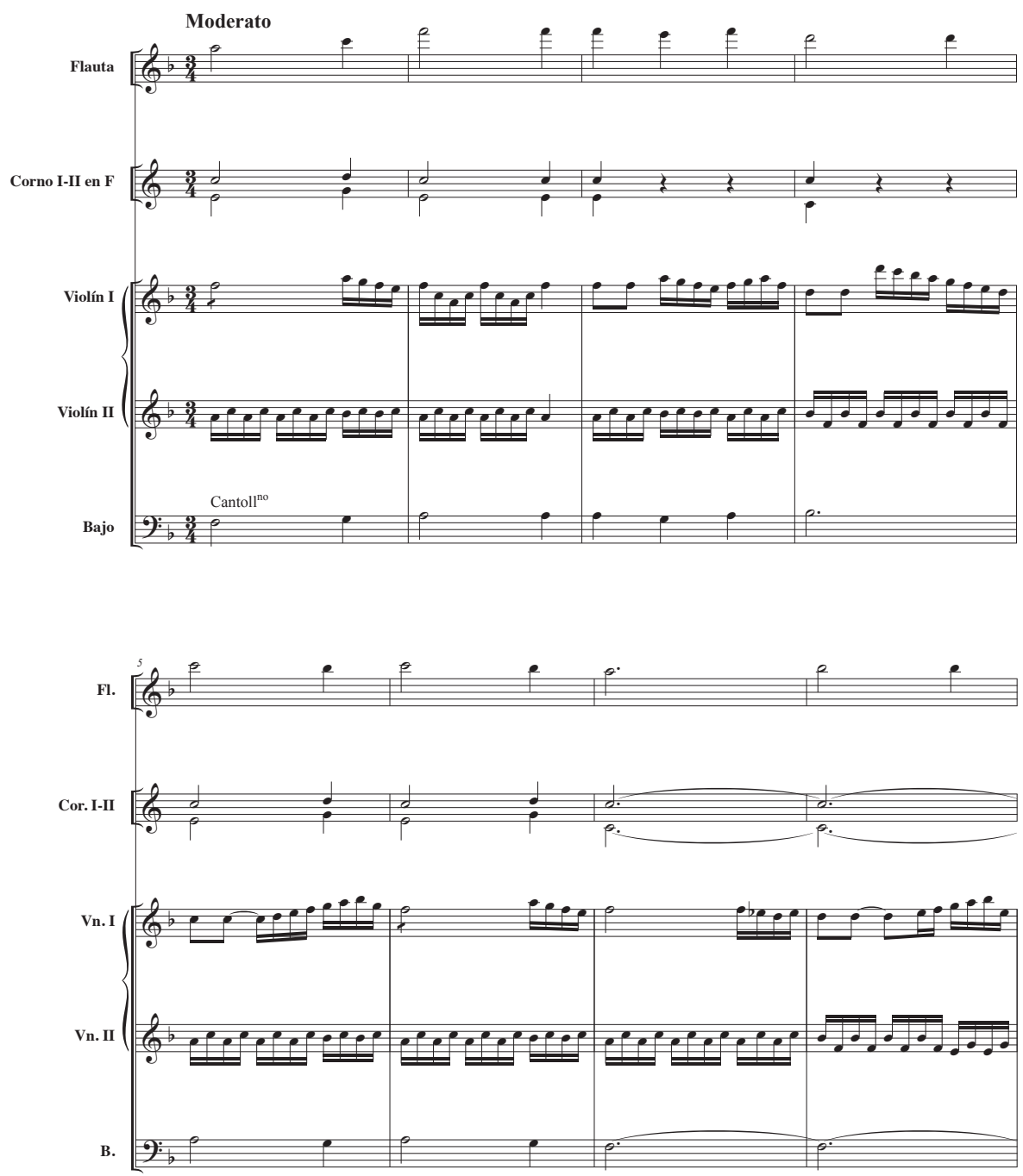

Ejemplo 2. Marcha $n^{\circ} 3$ para la procesión del Corpus Christi compuesta por el violinista Juan Fernández para la Catedral de León en 1809 (continúa en las páginas siguientes) 

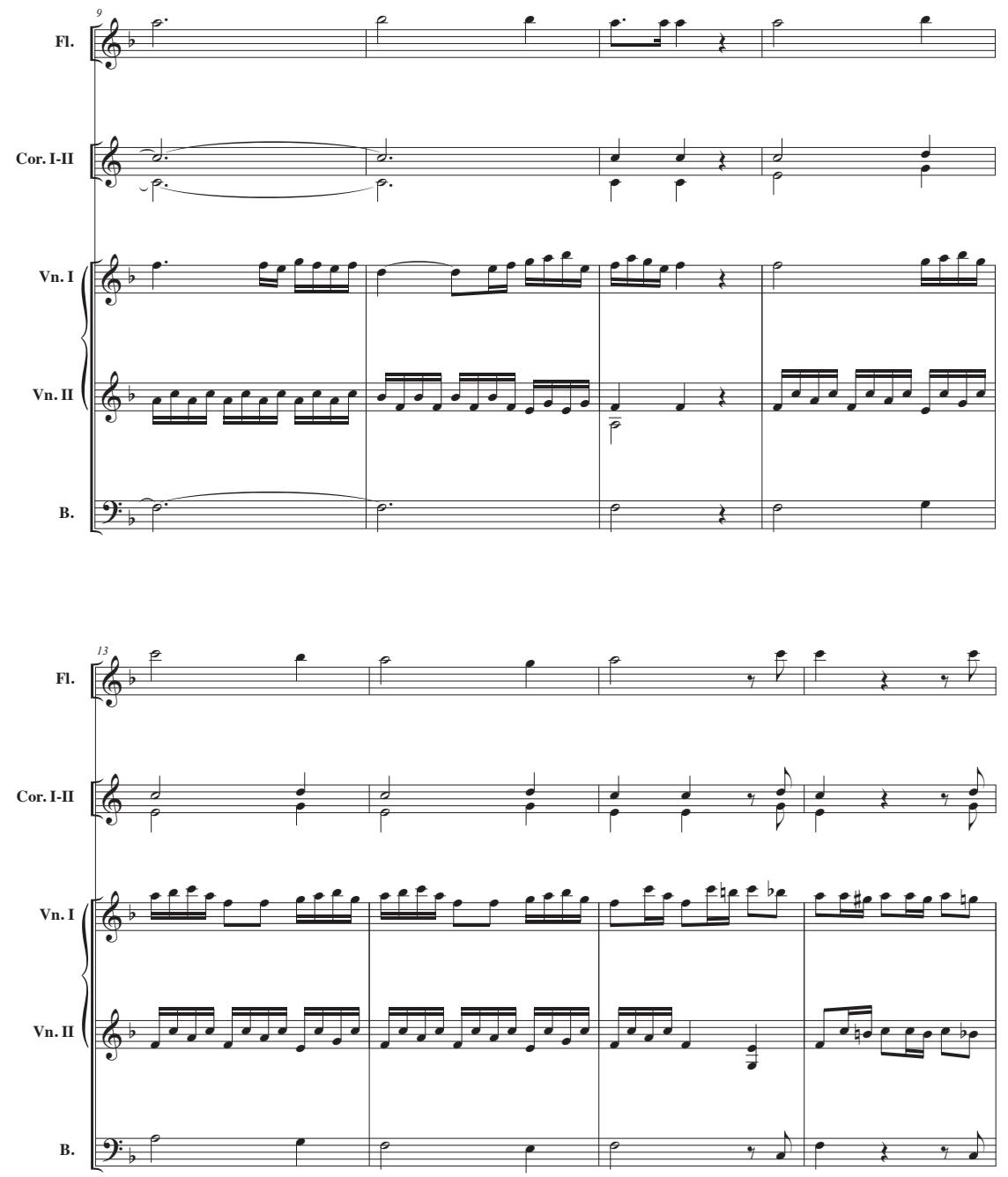
"Versos y marchas para las procesiones": música instrumental durante los desplazamientos... 83
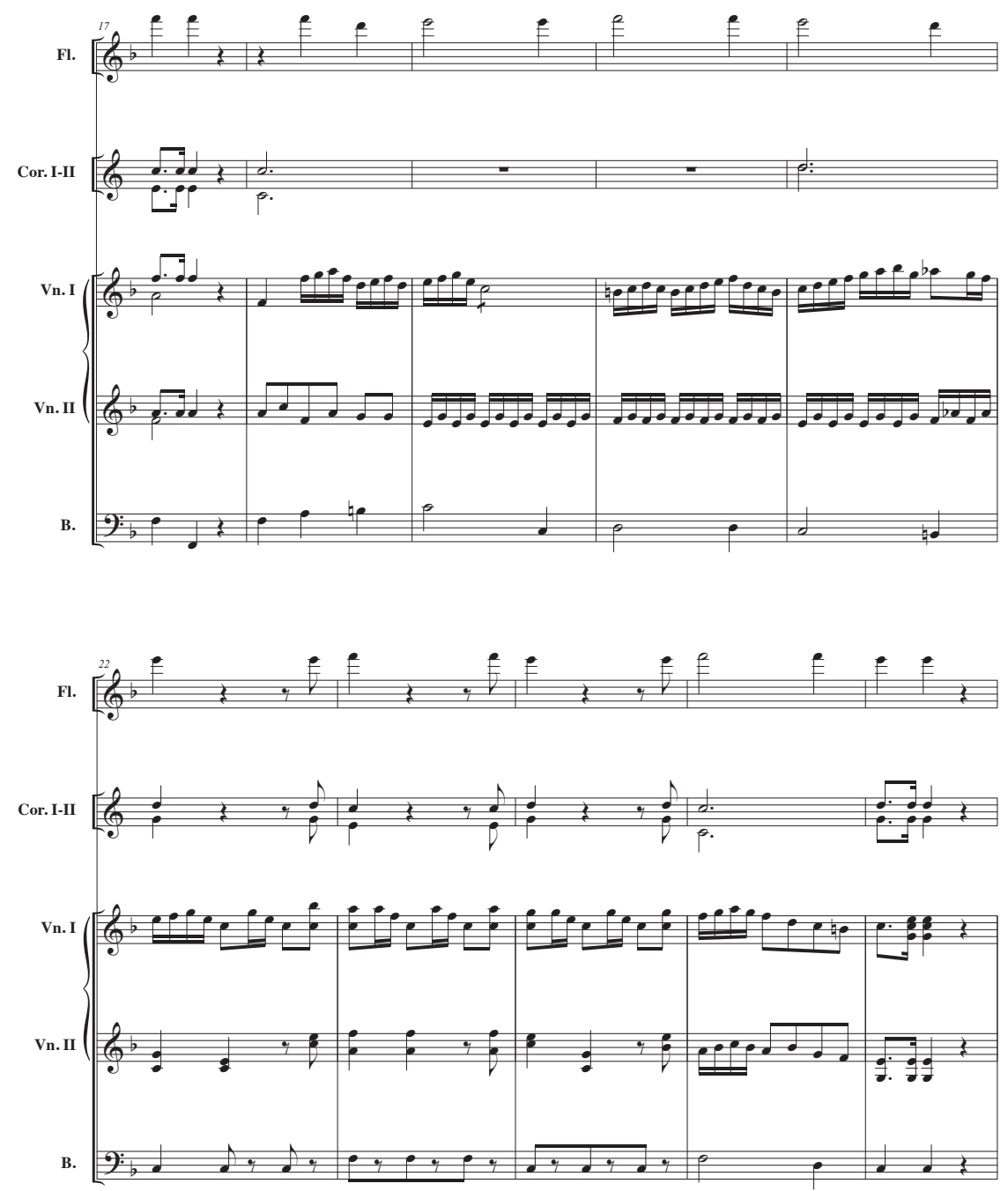

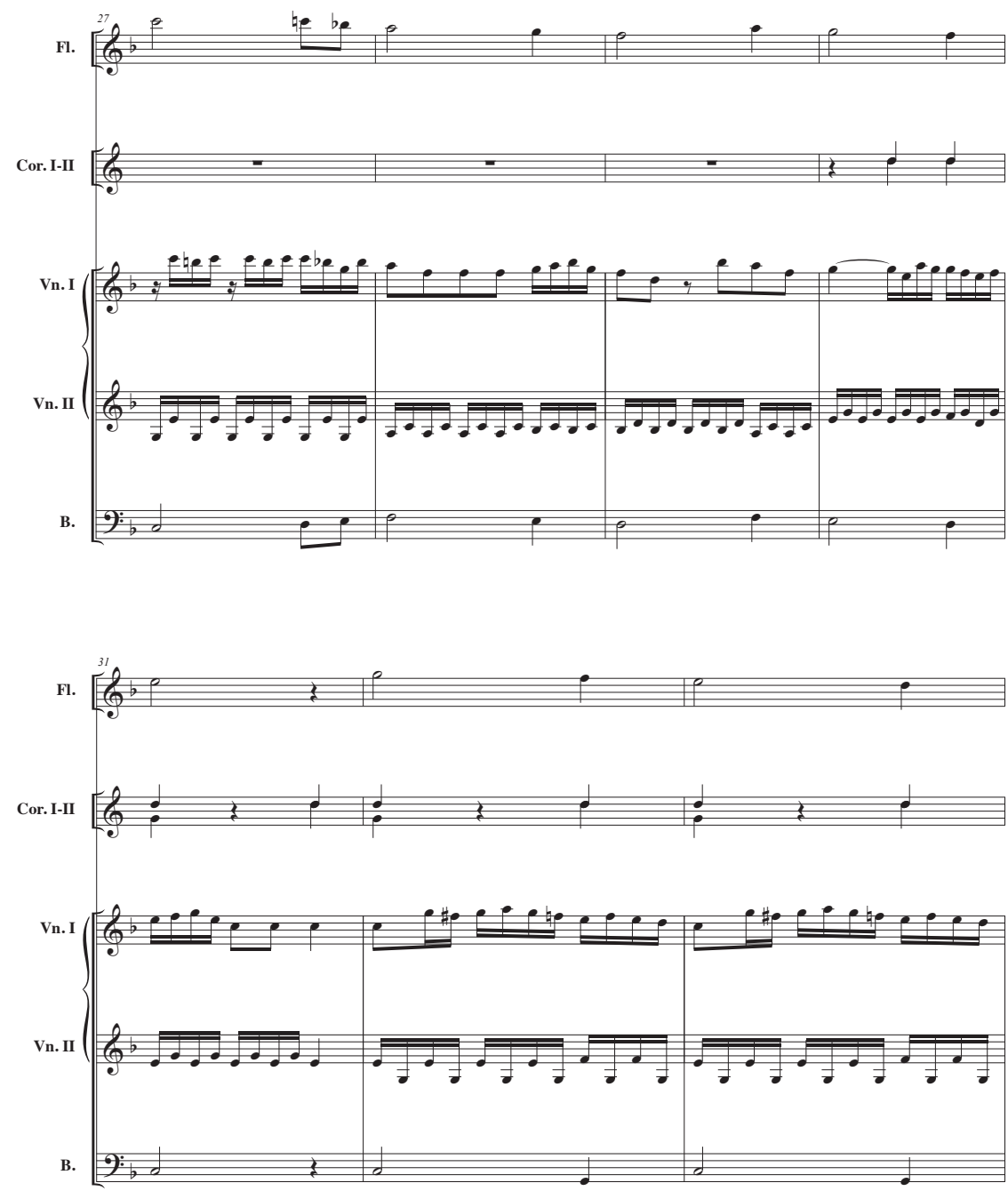
"Versos y marchas para las procesiones": música instrumental durante los desplazamientos... 85
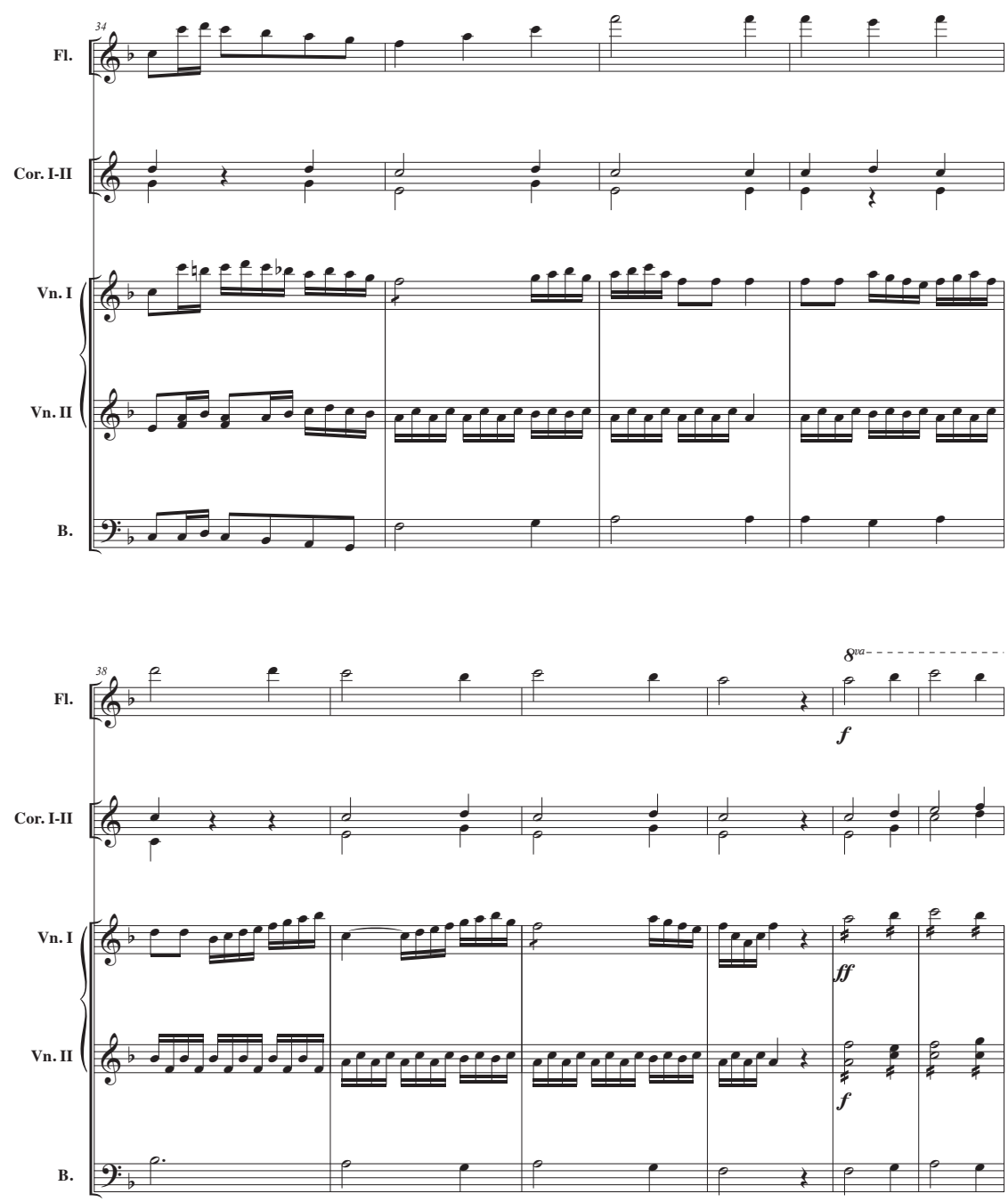


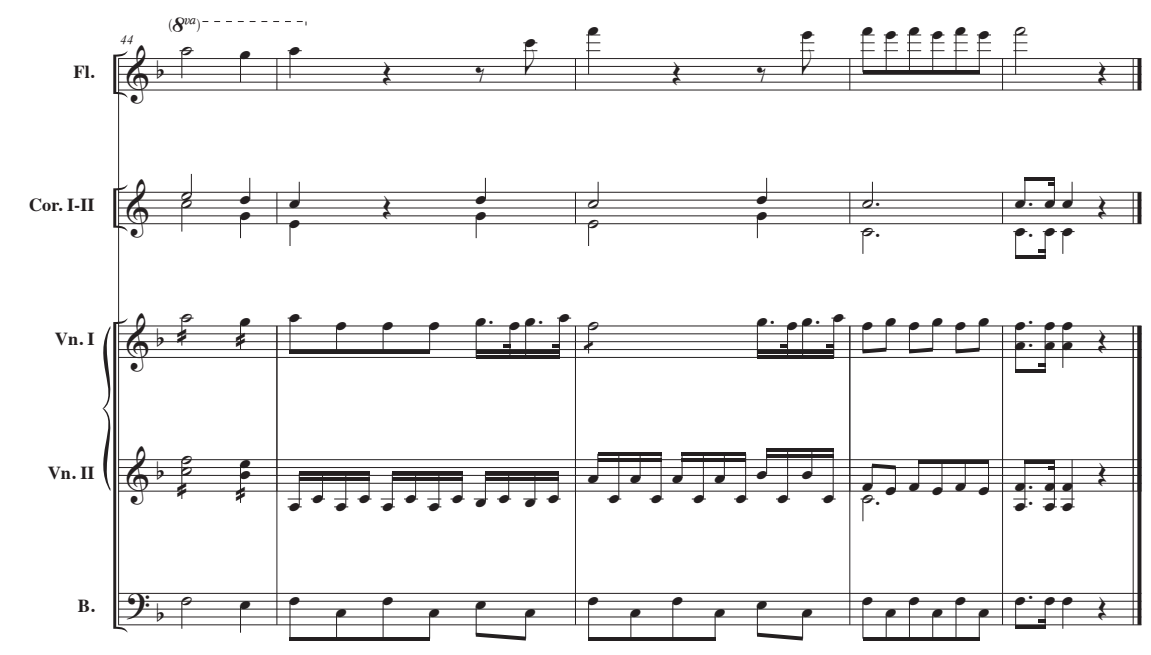


"Versos y marchas para las procesiones": música instrumental durante los desplazamientos... 87
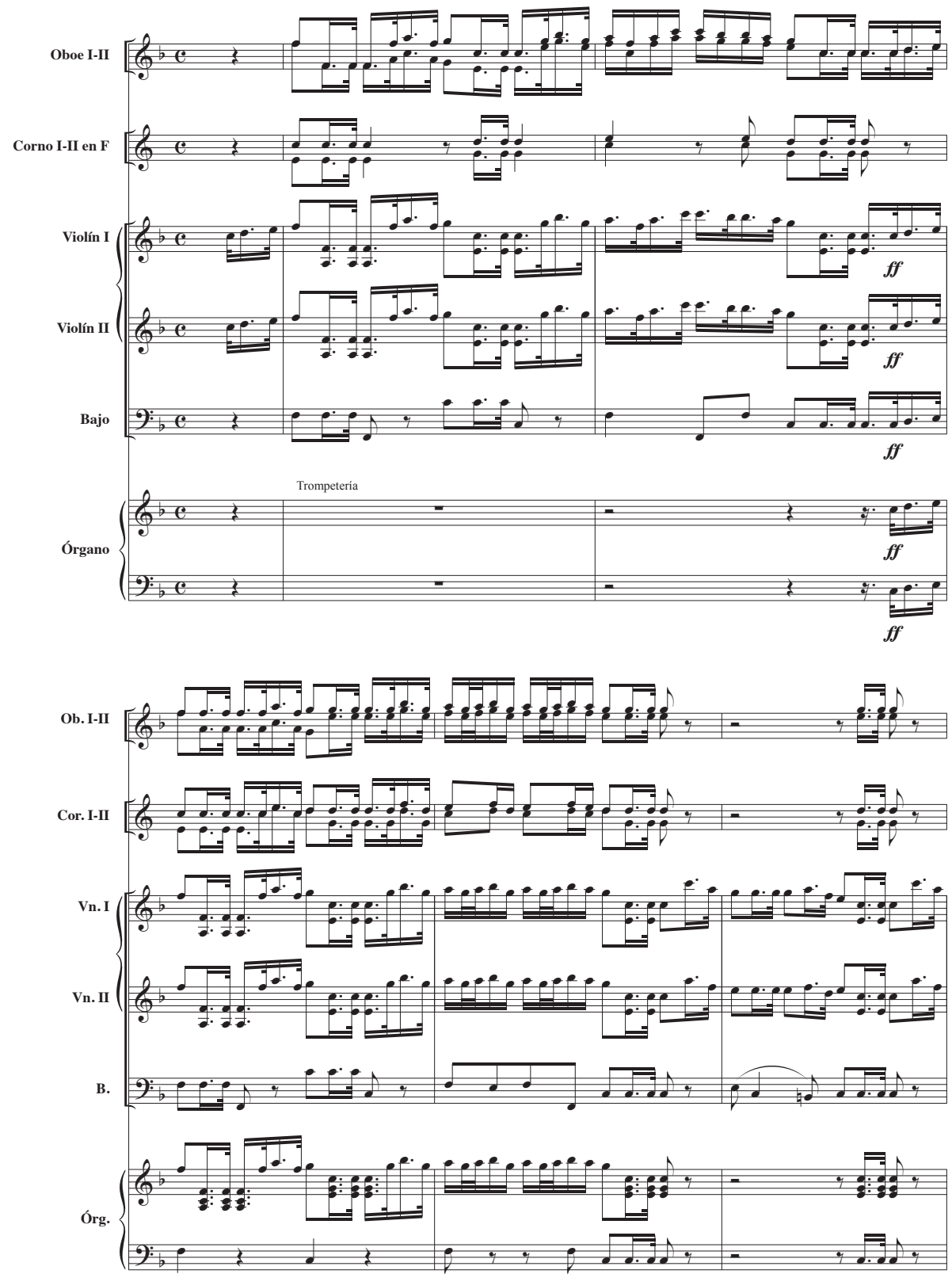

Ejemplo 3. Marcha $n .^{\circ} 4$ de autoría anónima conservada en un juego de cinco marchas, fechado en 1781, de la Catedral de Astorga (continúa en las páginas siguientes) 

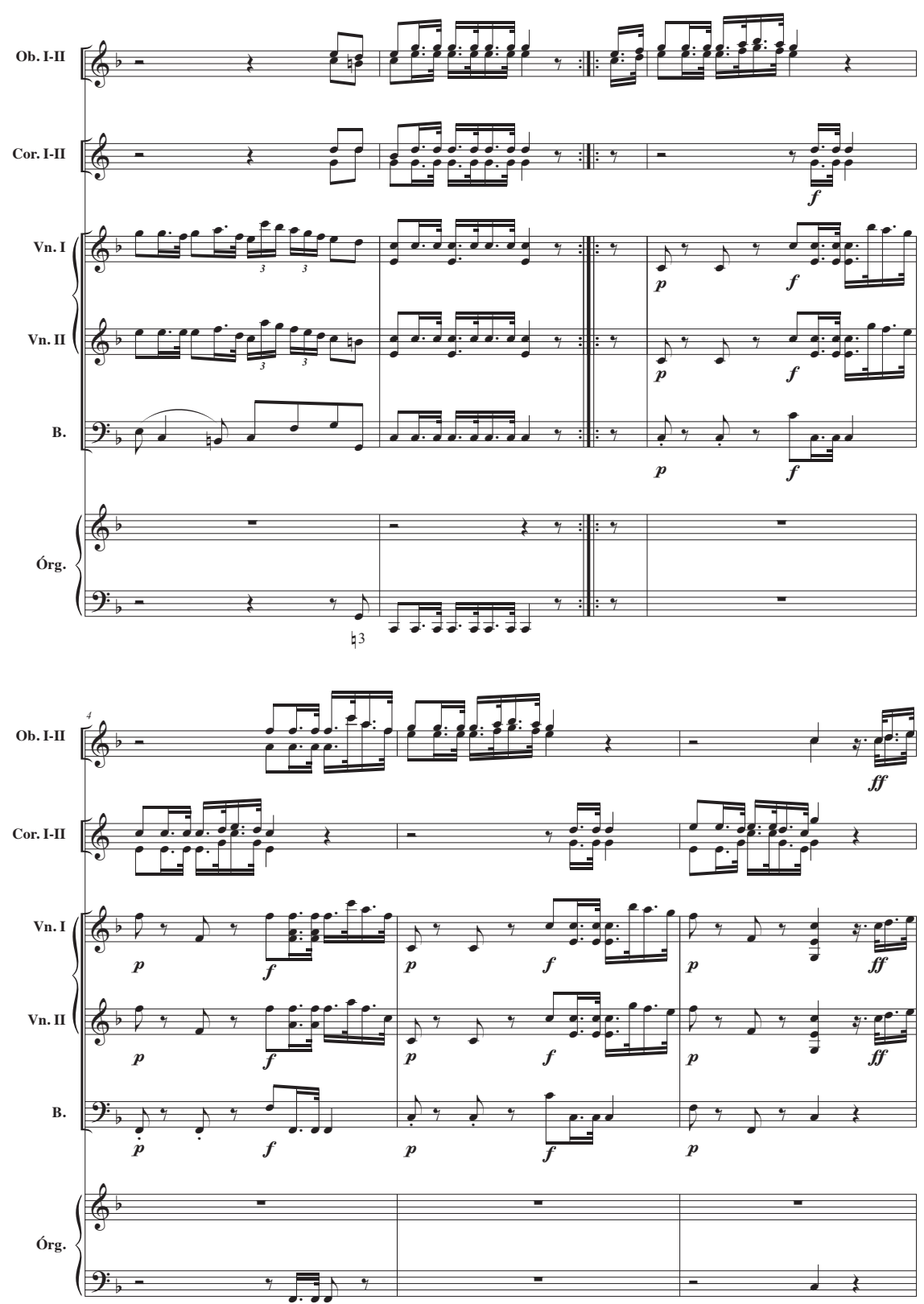


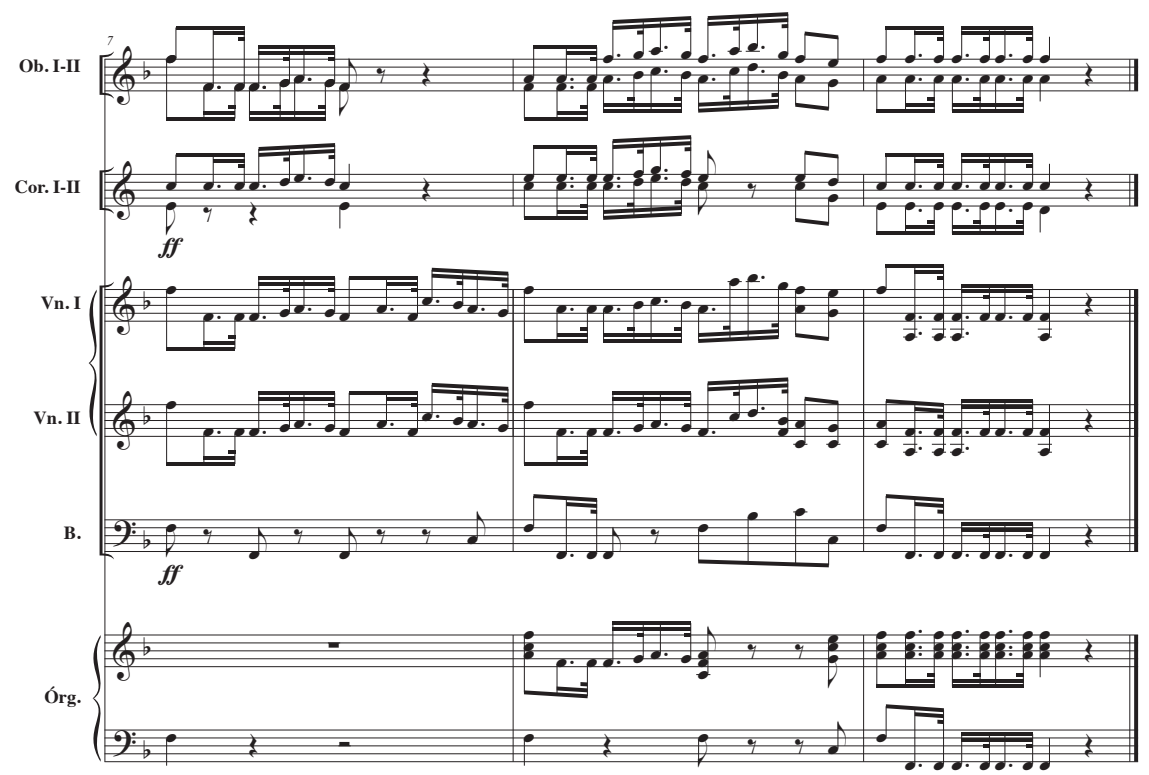



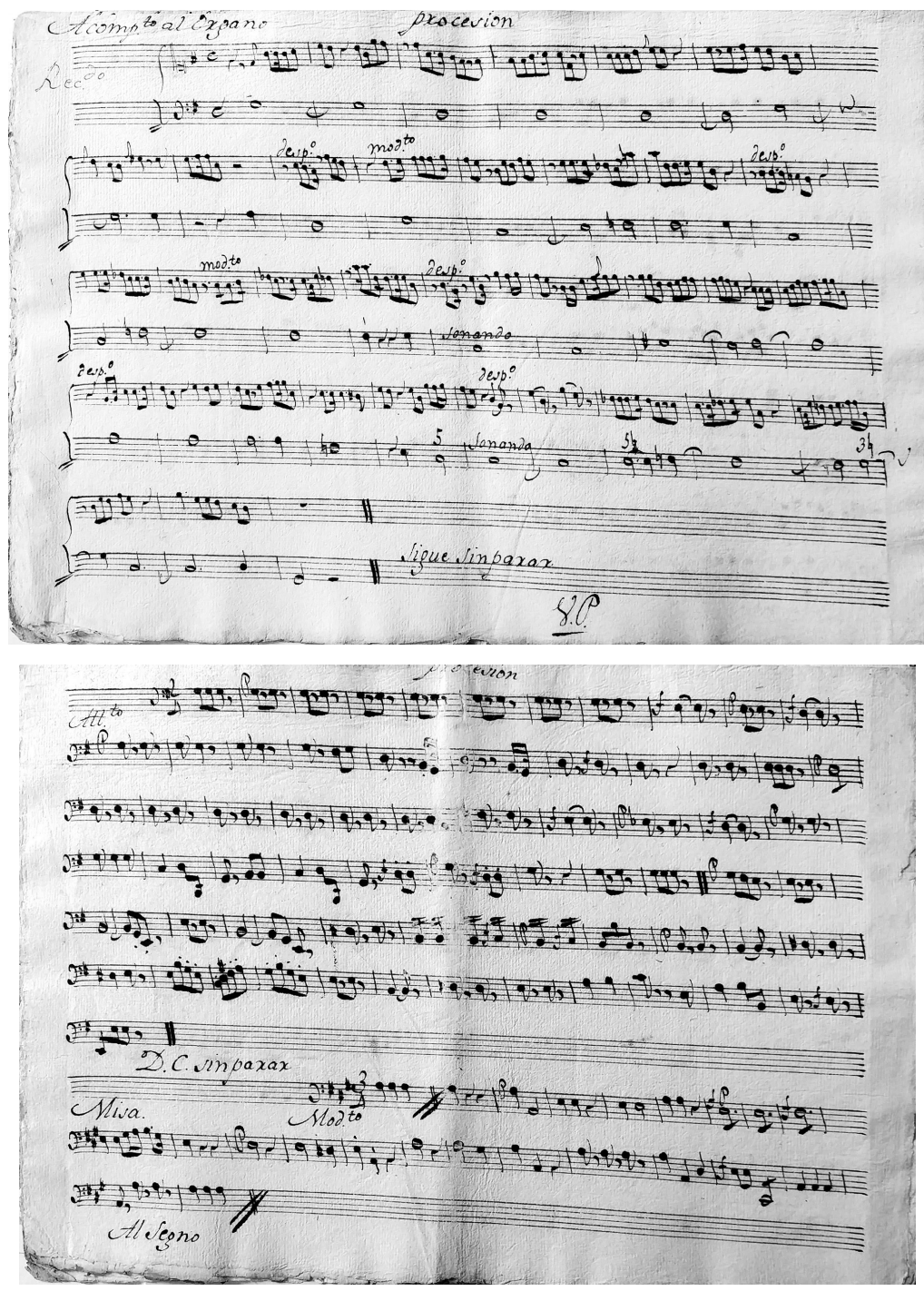

Ilustración 2. Recitativo, marcha para procesión y pieza instrumental para la misa. Archivo de la Catedral de Oviedo, legajo 44-2, partichela del órgano ${ }^{73}$

Recibido: 30-1-2020

Aceptado: 28-5-2020

${ }^{73}$ Agradezco a Agustín Hevia Ballina, archivero de la catedral ovetense, que me haya facilitado los permisos para reproducir esta fuente. 